Article

\title{
After Planning, the Production of Radical Social Space in Barcelona: Real-Estate Financial Circuit and (De Facto) Right to the City
}

\author{
Pedro Jiménez Pacheco \\ Department of Theory and History of Architecture, Polytechnic University of Catalonia, 08034 Barcelona, Spain; E-Mail: \\ pedro.sebastian.jimenez@estudiant.upc.edu
}

Submitted: 12 January 2018 | Accepted: 2 March 2018 | Published: 12 June 2018

\begin{abstract}
This article is based on the premise that it is possible to apply Henri Lefebvre's critical-theoretical apparatus to complex urban processes as a pedagogical case study. From previous knowledge of Lefebvrian thought, the article provides an overview of what Lefebvre called "the science of the use of social space", supported by a transdisciplinary methodological plurality. The starting point is that neoliberal social space is produced, prepared, and led to the imminent urban postneoliberalism, in the midst of this movement, a sophisticated planning system appears, with the old promise of service tradition, egalitarian ethics and pragmatic orientation. But in practice, it only reproduces the impotence of being inside a wave of localized surplus-benefits that expels human residues, avoiding any reaction. The Lefebvrian apparatus and a part of its theoretical tradition guide the research on Barcelona as a paradigm of global real-estate violence. This urban phenomenon is examined in central Barcelona, in order to rescue it from the pessimism of its own inhabitants, from the harsh perception that urban centrality no longer reproduces life. In this way, the article puts into operation an analytical tool designed to sabotage the real-estate circuit through a renewed right to the production of radical social space.
\end{abstract}

\section{Keywords}

Barcelona; Henri Lefebvre; production of social space; real state circuit; rental housing; right to the city; urban analysis

\section{Issue}

This article is part of the issue "Urban Planning and the Spatial Ideas of Henri Lefebvre", edited by Michael E. Leary-Owhin (London South Bank University, UK).

(C) 2018 by the author; licensee Cogitatio (Lisbon, Portugal). This article is licensed under a Creative Commons Attribution 4.0 International License (CC BY).

\section{Introduction}

Life is lived as a project, insisted Lefebvre, and his life, like that of Marx, must be seen as a totality of interests flowing simultaneously instead of fragmented pieces.

Upon examining doctoral research focused on updating and deepening of social space theory and urban criticism by Henri Lefebvre, we asked ourselves how we could use Lefebvre's thought together with his theoretical tradition and what in it is useful for us in the study of the contemporary city. The research stay in Barcelona has been decisive-because of the irruption of "the municipalism of change" in several Spanish cities in the sectional elections of 2015, as well as the promise of a program of "the commons" in the government of Barcelona city-for the selection of a unit of urban scale that allows us the orderly application of Lefebvrian methodological, theoretical and political formulations.

Aware of academic exploitation of the Barcelona old town's attributes in urban studies, we decided to interpret "Barcelona centrality's social space" (Appendix 1) as an ambiguous delimitation, from which the analysis extracts multi-scale spatial units with an explanatory capacity for the materialistic and subjective urban processes under capitalist logic at present. Strictly speaking, the article does not respond to the study of a case, confident in the inertial productivity of the research, but in some theoretical contents, applied in the city, capable of proving the effectiveness of the French theorist to take the architect along a transdisciplinary path ordered in the analysis of urban social space. In order to understand the relations, conflicts, resistances and hopes intertwined 
in space, revealing along the way the limits of municipal urban planning (in contradiction with urban legislation), facing a great wave of global flows of real-estate investment, and providing a theoretical-critical tool with a global focus for local struggles, largely dispersed and incapable of being integrated due to their fragmented visions of urban violence. Consequently, we clarify that the case study is not an end in itself in our research methodology; rather, we present it as a process of confrontation of the Lefebvrian approach-and-theory with a specific urban reality, which acquires an instrumental and pedagogical category in the whole article.

The article is based on our epistemological study of Henri Lefebvre's thought that postulates the notion of the radical social space as a possible (virtual) object at the service of the transformation of urban life and resistance (Jiménez Pacheco, 2016a, 2016b). Likewise, we start from the previous study of the Lefebvrian method of social space analysis. The formal and material reality of the social space (Figure 1) and its attributes (interpenetration and superposition) are clarified through the theoretical-methodological analysis of space as a social reality in the work of Lefebvre (Jiménez Pacheco, 2017b). This background led us to adopt its tripartite method (formal, functional and structural) of spatial analysis (Figure 2), supported effectively by other Lefebvrian classifications for understanding of complex urban reality. The support classifications are: the "levels" (Appendix 2) of social space, the semantic dimensions of urban space, and the urban phenomenon properties: projection of so- cial relations, confrontation of urban strategies and urban practices (Figure 3).

The article raises the methodological premise under which only the simultaneous operation of these classifications provides a "grid" that orders the Lefebvrian complexity of tripartite spatial analysis in Lefebvre's searching for a "science of the use of social space". The assembly of this grid integrates the fundamental levels proposed by Lefebvre in The Urban Revolution of 1970 to adapt and apply them in central Barcelona (Figure 3). The hierarchy of levels (private, mixed and global) is given by the radical Lefebvrian consideration of giving priority to "habiting" and primacy to the "urban" (Lefebvre, 1970/1972a). The grid is deployed with Lefebvrian concepts and existing factors (dispossession of housing, mass tourism, housing mafias linked to drug trafficking, the independence issue, terrorism, etc.) often involved, in a confusing way in the mode of spatial production in Barcelona (Appendix 3). Thus, the grid guided the process of concatenation of the concepts applied to the case study, articulating an emancipatory discourse of a concrete urban reality in Barcelona; giving as a result the guidelines of the counter-project of conquest of urban centrality animated by what we call "de facto Right to the City" (Jiménez Pacheco, 2015, 2017b).

The research is divided into two large parts. In the first, the essential characteristics of the urban phenomenon in Barcelona are analyzed. Following Lefebvre (1970/1972a), land-ownership is the most important social relationship in the capitalist city. The projection of

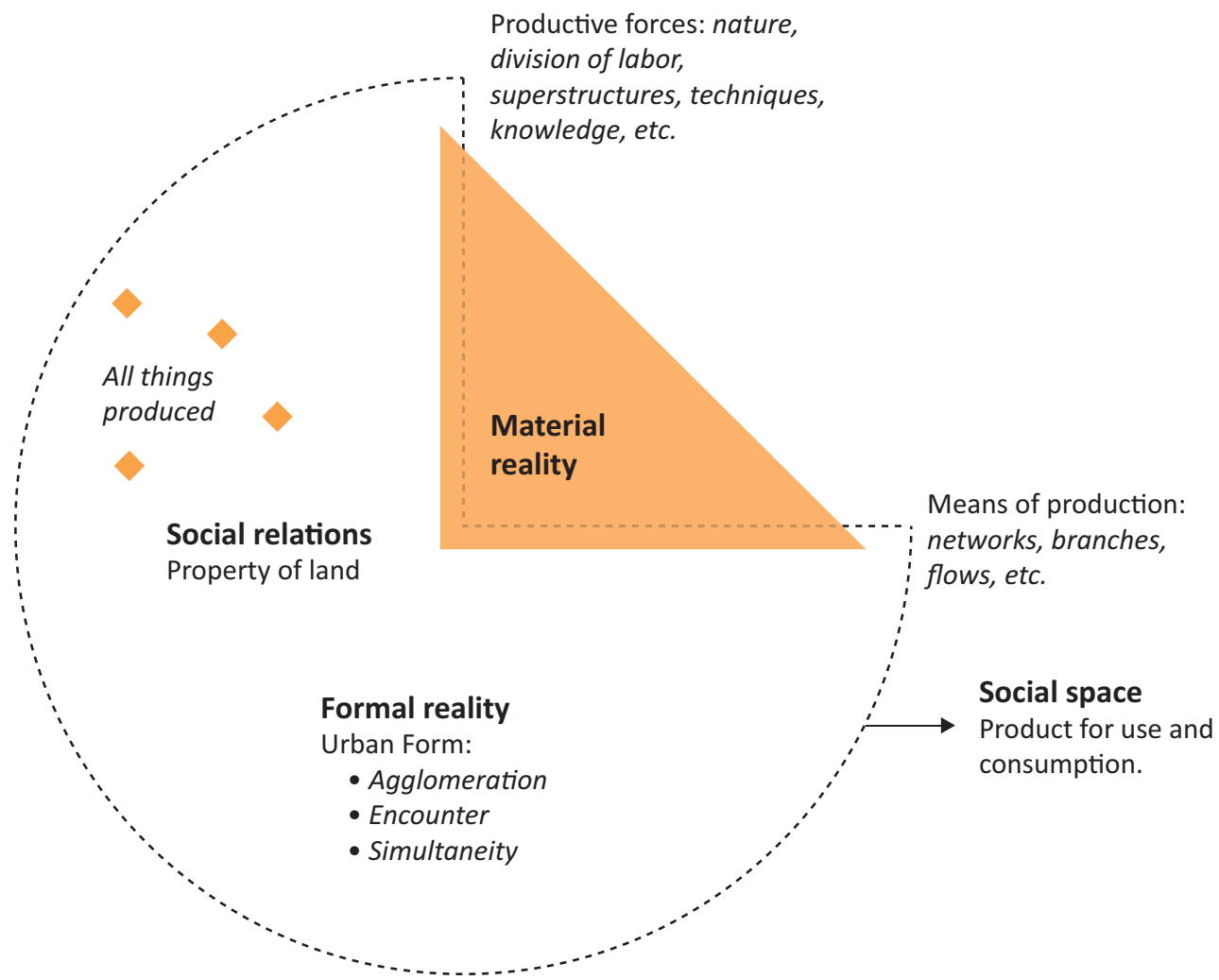

Figure 1. Diagram of the complex reality of social space. Source: Jiménez Pacheco (2017b). 


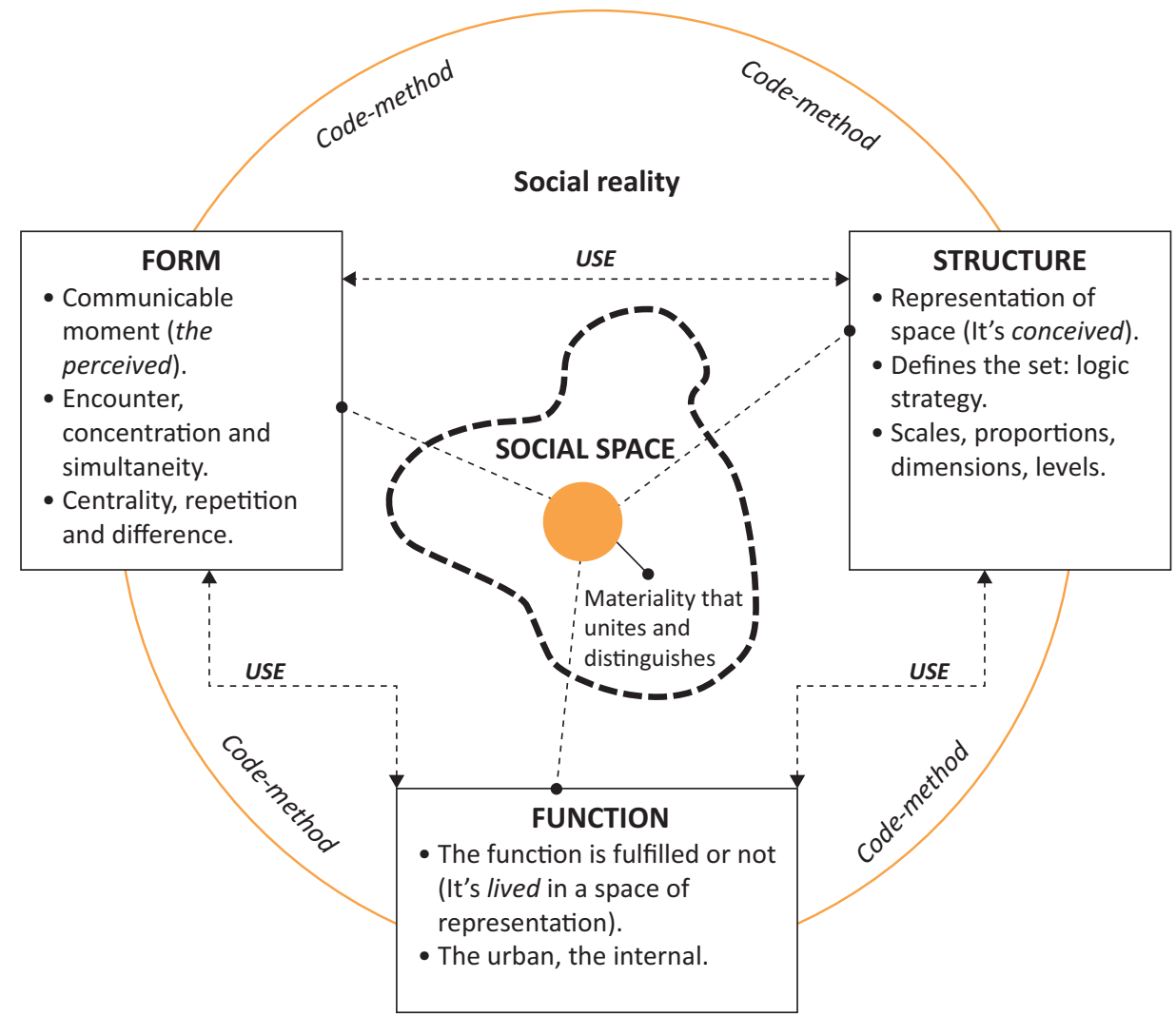

Figure 2. Diagram of the Lefebvrian methodological-theoretical analysis of social space as a social reality. Source: Jiménez Pacheco (2017b).

\section{Scheme of Social Space Analysis: Primacy of the urban \& Priority of habiting}

\begin{tabular}{|c|c|c|c|c|c|}
\hline \multirow{3}{*}{$\begin{array}{l}\text { Urban } \\
\text { Phenomenon } \\
\text { Properties }\end{array}$} & $\begin{array}{l}\text { Projection of } \\
\text { social relations }\end{array}$ & $\begin{array}{l}\text { Multiplicity of juxtaposed, overlapped, } \\
\text { conflictive markets or not: products, } \\
\text { capital, labor, works and symbols, } \\
\text { inhabitant and land. }\end{array}$ & \multirow{3}{*}{$\begin{array}{l}\text { Private } \\
\text { (P) }\end{array}$} & \multirow{3}{*}{$\begin{array}{l}\text { Mixed } \\
\text { (M) }\end{array}$} & \multirow{3}{*}{$\begin{array}{l}\text { Global } \\
\text { (G) }\end{array}$} \\
\hline & $\begin{array}{l}\text { Confrontation } \\
\text { of strategies }\end{array}$ & $\begin{array}{l}\text { Means and instruments of action, at all } \\
\text { levels (institutions, agencies and urban } \\
\text { agents). }\end{array}$ & & & \\
\hline & $\begin{array}{l}\text { Urban } \\
\text { practices }\end{array}$ & $\begin{array}{l}\text { Specific reality and vitality (neither spatial } \\
\text { ideologies and their organization, nor } \\
\text { urbanistics practices). }\end{array}$ & & & \\
\hline \multirow{2}{*}{$\begin{array}{l}\text { Science of } \\
\text { the Use of } \\
\text { Space }\end{array}$} & $\begin{array}{l}\text { Formal } \\
\text { Analysis } \\
\text { Functional } \\
\text { Analysis }\end{array}$ & $\begin{array}{l}\text { The communicable moment in spatial } \\
\text { practice (is perceived). } \\
\text { It is fulfilled or not. (The lived) in the space } \\
\text { of representation. }\end{array}$ & $\begin{array}{l}\text { Habiting } \\
\text { (housing). }\end{array}$ & \multirow{5}{*}{$\begin{array}{l}\text { Intermediate } \\
\text { between the } \\
\text { private and the } \\
\text { global. City, } \\
\text { unity of social } \\
\text { reality: Streets, } \\
\text { Rambla of } \\
\text { Barcelona, } \\
\text { neighbourhoods, } \\
\text { Ciutat Vella } \\
\text { District, } \\
\text { Barcelona city, }\end{array}$} & \multirow{5}{*}{$\begin{array}{l}\text { The State, the } \\
\text { powers and the } \\
\text { knowledge of } \\
\text { the global scale, } \\
\text { the institutions } \\
\text { and the } \\
\text { ideology. Scale } \\
\text { from concrete } \\
\text { abstraction. } \\
\text { City-Region: } \\
\text { Catalonia, } \\
\text { Region-State: } \\
\text { Spain, } \\
\text { State-Bloc: } \\
\text { European Union } \\
\text { Bloc-Worldwide. }\end{array}$} \\
\hline & $\begin{array}{l}\text { Structural } \\
\text { Analysis }\end{array}$ & $\begin{array}{l}\text { Representation of space (is conceived) as } \\
\text { links between the whole and the parts, the } \\
\text { macro and the micro. It considers scales, } \\
\text { proportions, dimensions and levels. }\end{array}$ & & & \\
\hline \multirow{3}{*}{$\begin{array}{l}\text { Semantic } \\
\text { Dimensions } \\
\text { of Urban } \\
\text { Space }\end{array}$} & Paradigmatic & $\begin{array}{l}\text { Set or system of oppositions or topological } \\
\text { distinctions. }\end{array}$ & & & \\
\hline & Syntagmatic & Chains and connections, links. & & & \\
\hline & & $\begin{array}{l}\text { Ideologies and institutions, privileged } \\
\text { present or past places. }\end{array}$ & & & \\
\hline
\end{tabular}

Figure 3. Summary assembled grid for the Lefebvrian social space analysis. To see grid unfolded refer to Appendix 5 . Source: Jiménez Pacheco (2017b). 
property (land) relations suggests the analysis of a multiplicity of markets operating in Barcelona (labor, tertiary sector, cultural, innovation and knowledge, technology, etc.). However, for this study, it is delimited to the financial real-estate market and its specialization in rental housing, projected in the urban centrality (historically exploited as a leisure and tourist consumption space). From the critical theory of real-estate circuit in the city, we intend to shed light beyond the devices of a "concerted urban planning" inherited from past decades, and on who is behind the violence expressed in the mass tourism and dispossession of housing, and how the force relations of global capital flows operate through their terminals in space. This part of the research is supported by historical study to enable a contextualized reading of urban processes in recent decades in Spain.

The second part focuses on social space analysis in the Barcelona centrality, having a closer look at social conflicts and municipal urban planning in La Rambla: a "representational space" of Barcelona, a transfunctional axis, which divides into two, but also articulates the social space of the historic center. We chose La Rambla because of recent events of social, urban, and economicpolitical relevance that make up an urban scenario with complex, and yet optimal, characteristics for examining Lefebvrian theory and method: a) the municipal approval in 2017 of the "Urban Uses Plan of Ciutat Vella" and the "Special Urban Planning of La Rambla"; and b) the Barcelona City Council (BCC)'s launching of the international competition for the socio-urban transformation of La Rambla with the aim of recovering it for the local residents (veïns) in March of 2017 (Servei de Premsa, 2017). The relevance of these activities in the "global centrality" is producing an even more complex reality that we will try to explain with the tripartite Lefebvrian method. Based on these two components, the final section prepares the strategy for the production of radical social space in Barcelona, supported by the new right to the urban centrality: that makes possible the production of another social space.

Data sources used for this article can be separated into two blocks. The first block corresponds to the complete literature Lefebvre obtained for his doctoral research, plus the primary data sources collected in interviews with institutional and external actors, access to municipal documents of urban planning, municipal statistics, reports and minutes of citizen participation meetings, as well as access to financial and real-estate market analysis reports. The second block is the secondary academic sources of historical character and relevant literature of experts, together with the review of the newspaper library and diverse journalistic sources.

\section{The Real-Estate Financial Circuit in the Capitalist Urbanization}

Lefebvre (1967/1972b) in his work Vers le cybernanthrope (contre les technocrates) believes that a revolu- tionary urbanism is possible, but that it will not be a matter of preparing socio-technocratic projects, the expert efficacy of the specialists who lean on the needs of the population to evaluate them will not suffice. Therefore, those interested should take the floor, and the task will be to listen to the human, without philanthropic humanism. The conception of the Possible is not based on the analysis of the actual but on the criticism of the actual, disaggregated by analysis, ideology and strategy. For Lefebvre (1970/1972a), the planning activity and the urbanism form an illusion, an ideology to justify the technocratic utopia, leaving a fundamental void when trying to supplant urban practice with representations of the space and the social life of urban groups. The French theorist found that urban planners were almost totally unaware of productive activity in organizational capitalism. The extension of the secondary circuit (until that moment) of capitalism was no longer satisfied with the soil or the land, but the social space as such. This implied space not only as the sum of places where surplus value is realized and distributed, but also as a product of social work in the formation of surplus value.

In The Production of Space, Lefebvre (1974/1991) announced the production process of a specific space, based on the differentiation in modes of production. Thus, the perimeter of the Mediterranean became the leisure space for industrial Europe; settling on these new spaces-of pleasure and non-work-the neocolonialism, which manifests itself in the social and economic fields, but also in the architectural and urbanistic fields. Then a space of unproductive expenses emerged, a great waste of things, symbols and energies (Lefebvre, 1974/1991).

Starting in the seventies, at the beginning of the flourishing of financial capitalism, Henri Lefebvre pointed out what would be the renewed objective of capital in the face of the profitability crisis caused by the exhaustion of the industrial-Fordist model of the glorious thirty years: the real estate sector and the construction sector would cease to be a secondary circuit, an annexed and delayed branch of industrial and financial capitalism, and move into the foreground of the new accumulation matrix. There are few better illustrations than Spain, and in particular Barcelona, of this drastic transformation of the economic structure towards the revaluation of urban land and space as the favorite assets of financial capital.

According to M. Gottdiener (2000), Lefebvre's most important contribution to the analysis of the built environment is his conception of the real estate market as a second capital circuit. This implies that the components and the dynamics of investment in the land constitute a sector of the economy that is somewhat separated from the primary circuit of industrial production and commercialization. On the one hand, the circuit is composed of financial elements, such as banks, property companies, and state programs or regulations, and, on the other hand, by individual and group investors, speculators, homeowners, and anyone who acts to earn 
money from the land. Lefebvre believed that investment in the second circuit was healthy only to some extent, because the primary circuit and its exploitation of value created workers. However, with the low organic composition of real estate capital, real estate is almost always an attractive investment, so it can often get money from the primary circuit.

Investment flows of the second circuit are cyclic just like in the primary circuit, but they are not synchronized. For this reason, the practice of real estate investment also depends on both the level of investment and the profitability in the primary circuit. Capital responds to differences in opportunities for profitable investment in these two circuits, changing from one to the other in search of the highest profitability. Like Gottdiener, we think it is surprising to see some researchers still attribute to Harvey the idea of separate circuits. In the 1970s, Harvey (1973/2014) made a notable contribution in applying Lefebvre's ideas to real estate investment in American cities and extended this approach in a useful way. But Lefebvre's ideas, as outlined in Marxist Thought and the City (1972/1983) and The Production of Space (1974/1991), continue to be contributions based on the critique of political economy that provide ideas that have yet to be fully exploited by the current generation (Gottdiener, 2000). Gottdiener's criticism is based on the fact that, since the 1980s, Lefebvre's contribution has evaporated rather quickly without being truly taken advantage of. It raises, for example, the possibility that the disciplinary limits were defended aggressively, and an evident careerism had been established in the urban studies that guided previous intellectual efforts. In short, the cumulative project of urban science had been effectively abandoned.

In Marxist Thought and the City, Lefebvre (1972/1983) explains the functions and structures of the urban form linked by history to bourgeois society, to surplus value in its formation, realization and distribution processes. The city comes to the forefront in the realization of surplus value (economically speaking). The extension of the market is linked to the urban phenomenon and the city protects that market. During economic crises, the currency no longer works in its ideal form, liquidity is needed, and, without it, merchandise stagnates and goes bad. "The city is the theatre of these bourgeoisie dramas that resound on the various fractions of people, destined for unemployment because the rich no longer have money" (Lefebvre, 1972/1983, pp. 118-119). In Critique of the Gotha Programme, Marx (1875/1977) explained to the labor movement that, in a society, we need artists, fun professionals and so on. But in such a society there are also parasites, Lefebvre explains-the speculators who want their money to "work" and make more money directly (Figure 4). The distribution of surplus value passes through the highest levels of global capitalist society, that is, national and global. The maximum possible social surplus product would go to investments and consequently to the "uses" of those productive investments, facilitating the accumulation and investments forecast.

According to Lefebvre (1972/1983, p. 135), "the theory of the real-estate (with its own characteristic: ground rent and commercialization of space, capital investments and profit opportunities), for a long time a secondary sector, progressively integrated into capitalism, is still under development". This "critical theory", he says, deals precisely with the process of integration, of subordination to capitalism of a long time external sector. Marx's texts on real-estate capitalism and its income come to this theory, without developing it but indicating and sketching it. In addition, Lefebvre explains, the symbolic role of real-estate ownership surpasses many of its quantitative real economic effects. "Real estate drags back the entire society; not only slows its growth and paralyzes development, but guides it by a constant pressure" (Lefebvre, 1972/1983, p. 135).

\section{GRUPO INVERSOR}

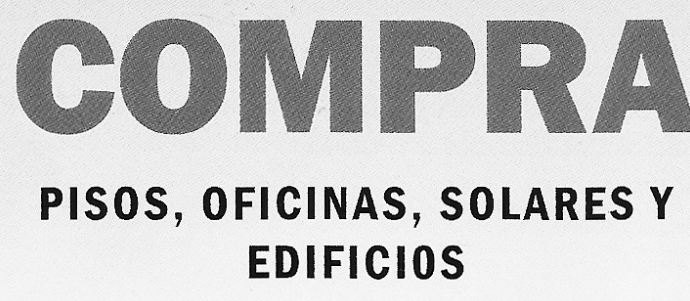

En cualquiler estado u ocupación.

\section{Avanzamos gastos de herencia; hipotecas y otras.}

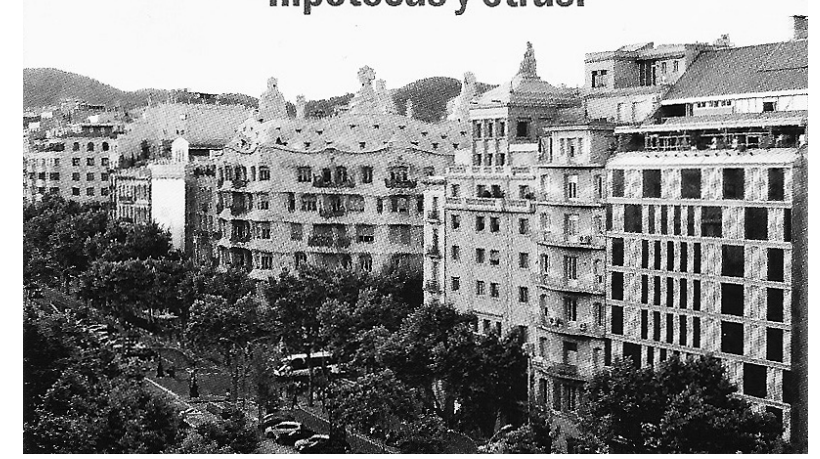

Figure 4. Investor announcement for a real-state purchase; they are commonly found in the accesses to residential buildings in downtown Barcelona. Source: unknown, collected in a residential building of Sant Antoni neighborhood.

Topalov (1978) develops Lefebvre's concern about the capital cycle in the real-estate sector of the capitalist production system. Our interest is to focus mainly on rental analysis. Thus, rentier real-estate capital (RRC) functions 
as circulation capital for promotion capital: the rentier invests in a property, and thereby allows the promoter to recover his contribution and his profit. The RRC cannot expect to obtain the average profit for its investment, but only the interest: in a manner comparable to the shareholder that contributes to finance production, and in return receives only the interest rate, the annuity contributes to financing the circulation, and therefore, the production of the building. But pay attention, the cycle of the RRC extends throughout the physical life of the property. In effect, during the life of the building, the production of the building continues. It is evident that the amount of the rent, half a century later, has nothing to do with the interest on the initial investment cost. What determines it, then? Topalov shows that they are the current conditions of real estate production: the price of new real estate regulates the price of old real estate. However, the prices of newly produced properties depend, at the same time, on the evolution of the prices of production of buildings and the evolution of localized profits, of ground rents.

The economic calculation of the real estate developer in the capitalist city is considered as the determining operation of the urban land market. The distribution of surplus profit (SP) between the developer and the owner will be the result of that social relation between capital and land-ownership called: the "land market" (Topalov, 1978). This is how the SP can be divided into two parts: one is the promotional SP that, for the promoter, goes purely and simply to be integrated into total profit; the other is the land price, that is, part of the localized-SP that will be transferred to the owner. Topalov explains that it is not the rent that determines the price: it is the price that determines the rent. The determining element of the formation of the land's price is its capitalist demand price, which is fixed by the localizedSP that capital creates thanks to the valuation of landownership (Topalov, 1978).

\subsection{The Rental Real-Estate Bubble in Barcelona}

López and Rodríguez (2013) study the aspects of the political economy of the Spanish territory within a regime of "successful accumulation" in the framework of financialization, globalization and neoliberal command, based on the intensive use of territorial assets. Under this scheme, they argue that the political economy after the 1973 crisis created a geography tailored to the needs of the growing financialization of capital, which, associated with impositions of the new neoliberal government, is considered the great solution to the crisis of profitability that at least in the western bloc determined deregulation and financial liberalization. "The consequence of financialization, in spatial terms, is a complete reordering of the relations between the new capitalist formations and their concrete geographies" (López \& Rodríguez, 2013, p. 234). The geographical scales are diversified: so-called globalization follows the discharge of certain strategic functions, linked to transnational competition, in regions and cities. At the same time, financialization stimulates and mobilizes an increasingly intensive use of territorial assets that are put at the service of the maximum expansion of progressively financial real-estate markets. In this sense, the Spanish growth of the years 1995-2007, which rode hand in hand with the most sustained and profound real estate cycle in the history of the planet, should be considered not as a strange and aberrant economic anomaly, but as a canonical example of these accumulation models.

As this competitive advantage was consolidated in Spain and became a territorial specialization (Charnock, Purcell, \& Ribera-Fumaz, 2014), the income capture model also varied from what could be called "direct tourist rents" (consumption demand from wage origin from the industrialized countries), towards a model in which the "Spanish tourism real-estate machine" began to attract large flows of transnational capital. Perhaps this progressive overlapping of income extraction models is one of the clearest representations of the continuous upward scaling of the Spanish secondary circuit. It is also interesting to note that while the Spanish coastal tourism-real estate model captured these rents, internally it developed a model of intensive exploitation of work in the services sector (Figure 5), quite far from the dynamics of increased qualification and union coverage that defined the labor models of the sending-countries of tourists. This exploitation model would anticipate the configuration of the next three decades of financialized spatial arrangements (López \& Rodríguez, 2013).

\section{Salarios reales}

Referencia de comparación $(2008=100)$

Fuente: Thomson Reuters/Financial Times

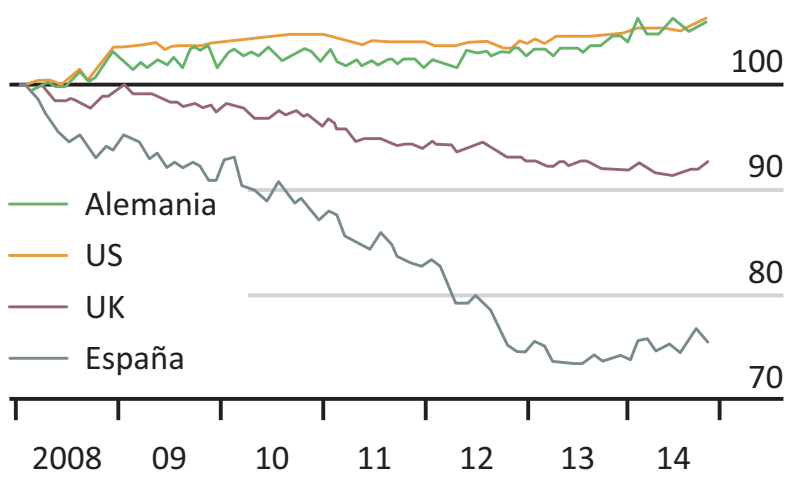

Figure 5. Real Wages 2008-2014. The average Spaniard lost $25 \%$ of his/her real salary in that period. Source: Thomson Reuters/Financial Times, in Idealista (2015).

2.1.1. The Socimist Revolution 2014-2017: Consensus in the Spanish Real-Estate Market

"Planetary urbanization" since the announcement of Lefebvre (1970/1972a) has always been a "revolution- 
ary" process. In the current global city, several dominant real-estate agents play that revolutionary role. The RRC that dominates capitalist cities is that of global speculators. Who is the agent that currently determines the demand price in Spain? The specialization of real-estate development in the Spanish financial market took the form of a Limited Investment Company in the Real Estate Market (Socimi). How do real-estate investment flows operate and evolve through these transnational organizations? In this part we review the analysis of the Spanish financial market to clarify the magnitude of the power that the global city faces. Consensus of the Market (CdM) is the group of financial analysts that replace the Spanish Institute of Financial Analysts.

The real-estate market regained strength as of 2014 due to the recovery of the Spanish macroeconomic environment; however, it lacks investment options for savers and the existence of good prices and profitability for savers. According to Díaz (2016), these are two sufficient reasons for citizens to transfer their money from bank deposits and fixed income to the purchase of housing. The author claims that the Bank of Spain showed that the profitability of housing exceeds $10 \%$ annualized with data for the second quarter of 2016, combining the increase in the price of apartments $(+6.3 \%)$ with rental performance (+4.6\%). This was accompanied by several Socimi created in 2009 (BOE, 2009), which focused on residential housing trading on the $M A B$, the Alternative Stock Market. (Ahorro Corporación Financiera, 2016). By the fall of 2016, it became clear that the construction sector benefited from the low profitability of fixed income and bank deposits (Díaz, 2016). However, for the analyst, the situation was still critical since the contribution of the construction sector to GDP had dropped to $47 \%$ and had barely recovered $8 \%$ from the minimum reached in 2013. By the end of 2016, the main question was whether the Socimi would rebound. F. Barciela (2016) made a balance at the end of the year stating that the four Socimi listed on the Continuous Market: Merlin, Axiare, Lar España and Hispania. This was representative, considering that the word "real-estate" continued to suffer from a certain public stigma, even among investors.

For Barciela, however, the market had doubts, especially due to the political instability in the Spanish government, which lasted long enough to push many investors to close positions in these securities, and to hold new investments expecting clear signals from the market. In some cases, the effects were aggravated since many investors present in these companies were foreigners. As soon as the bells rang, they gave the order to sell. Basically, the investors were pessimistic about a leftwing government and its pretention to review the legislation for the Socimi, especially its fiscal advantages (Barciela, 2016). Even before the investiture of Mariano Rajoy, these securities resumed their ascendant path of 2015. By 2016, the four major Socimi had a joint capitalization of $€ 7,687$ million, to which we should add almost 30 other small Socimi in the MAB.
The encouraging results by the end of 2016 forecasted a real 'success' for the real-estate market in the coming year. Testa Residencial started the year receiving 3,300 flats from the banks Popular, BBVA and Santander. By February 2017, it was announced that the used housing market rose by $7.37 \%$ thanks to new investors, who were already $28 \%$ of buyers. (Tramullas, 2017). Thus, the price of second-hand housing was recovering rapidly in Spain. According to the Housing Market Report (IMV), by the second half of 2016 the price reached $€ 1,690 / \mathrm{m}^{2}$, which represented an increase of $7.37 \%$ compared to the same period in 2015 . "It seems that investing in real estate does not produce the fear of previous years and investors who buy apartments to rent, especially in large cities, see it as an option in the absence of investment alternatives" (Tramullas, 2017). Nevertheless, to the chagrin of investors, this price was still far from the 2006 maximum $\left(€ 3,489 / \mathrm{m}^{2}\right)$. The bursting of the real-estate bubble inflicted a severe contraction in the market by devaluating the housing market $58.76 \%$ the first half of 2013 . Since then, the price has recovered 17.4\%; however, IMV Coordinator García Montalvo claimed there would not be a possibility for a new housing bubble. The coordinator explained: investment in new houses dominated the market during the years of the real-estate boom, but that situation will not return (Tramullas, 2017, p. 1).

José Benito de Vega (2017) analyzed the business model from Axiare (Socimi traded in the stock market in July 2014 , with a revaluation of $45 \%$. It was the best return of the Socimi listed). The business of Axiare consisted in the purchase of real-estate assets for exploitation through rent. The objective pursued by the company was to add value to the property and maximize its operating efficiency and profitability, in order to attract greater cash flows and a revaluation that translates into an attractive return for the shareholder. At the end of 2015, the company's portfolio was valued at 859 million, of which $72 \%$ were offices located in "premium" spaces in Madrid and Barcelona.

F. Barciela returns almost a year later after its forecasts issued in 2016 to show the encouragement of the sector and the reasons for its success:

Almost ten years after the burst of the real-estate bubble, Spain is once again excited about its particular ability to reactivate the real estate sector. The word is 'exciting' because of the spectacular revival of the sector-on which nobody wanted to bet three or four years ago. The reactivation is so strong that there is no day without euphoric news. (Barciela, 2017, p. 1)

Nevertheless, after the first semester of 2017, the IMV alerted for the first time about the possibility of a new bubble: "[i]f true (as some voices pointed out), the bubble would be very different from the previous one (and less harmful) since it is not based on credit but on savings" (IMV, 2017). The document points out that the 
potential risk is that the increase of the apartment rents in cities such as Madrid or Barcelona is pushing the demand of real estate. The feeling of "now or never" can put additional pressure on prices-this, together with the fact that the rental housing market showed stable growth in the last three years, registering a profitability close to $4.3 \%$ in the last quarter (a profitability much higher than most alternative assets). In some areas of large cities (like central Barcelona) with higher increases in the prices (Figure 6), "house-letting for tourists offers returns above double digits" (IMV, 2017). The report is consistent in pointing out that "nearly $30 \%$ of used houses are purchased by investors" (IMV, 2017).

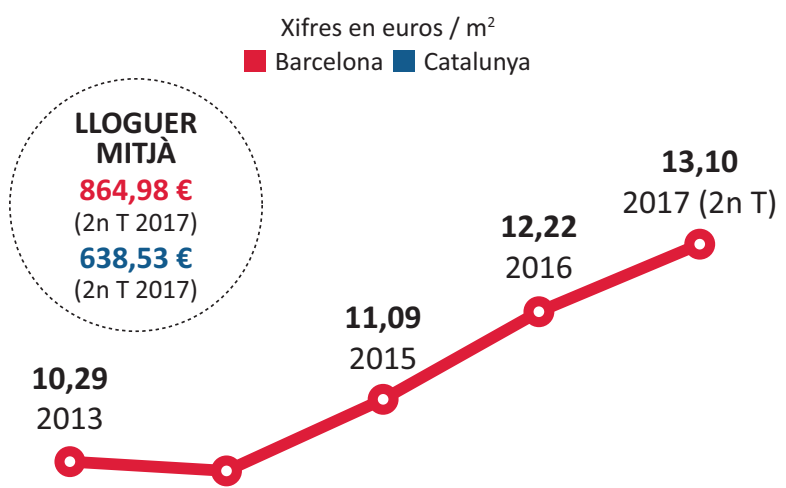

Figure 6. Barcelona rental price progress 2013-2017. Source: Institut Català del Sòl, in Ortega (2017).

\subsubsection{Main Drivers of the "New Bubble" and Its Social Consequences}

The analysts of the financial market agree that Spain is far from a new bubble (Díaz, 2016; Tramullas, 2017), but it is necessary to qualify its analysis. That it does not achieve the economic figures of the crash is one thing, but such logic does not mean that several cities such as Barcelona have not initiated an accelerated process of formation of a bubble with different effects from the one that caused the "great recession" since 2008. In the last two years, housing rents have climbed more than $25 \%$ in the "best prepared" neighborhoods of the tourist center and continue to accelerate while the evictions (Figure 7) for nonpayment of rent far exceed those of residents-owners. (Apilánez, 2017).

Jaime Palomera, founder and spokesman of the recently created Tenants Union of Barcelona, affirms that the Sindicat allowed them to realize to what extent they did not know the law that makes their life impossible. He gives the example of families in shock over the owner sending them a post announcing that they will now charge $€ 1,400$ instead of 700 . And if they do not like it, they have a month to leave. In other cases, tenants who have lived in an apartment for three years have received notice that the property has decided not to renew the contract, without any justification, and that they have 30 days to leave their home. Palomera explains that this attack is due, to a large extent, to the Ley de Arrendamientos Urbanos that is oriented to favor speculation, having been reformed in 2013 (BOE, 2013) to reduce the duration of rent contracts (from five to three years). This law allows any family, regardless of its history and relationship with housing, could be evicted if it is delayed in a single rent payment. Today, a family delayed in a rent payment and that has been denounced for it has only 10 days to make the payment and avoid the order of eviction (Sindicat de Llogaters, 2017).

After the big banks became the largest real estate in the country, it was necessary to remove that huge stock of housing from mortgage evictions from the market (Apilánez, 2017; Palomera, 2015). The government

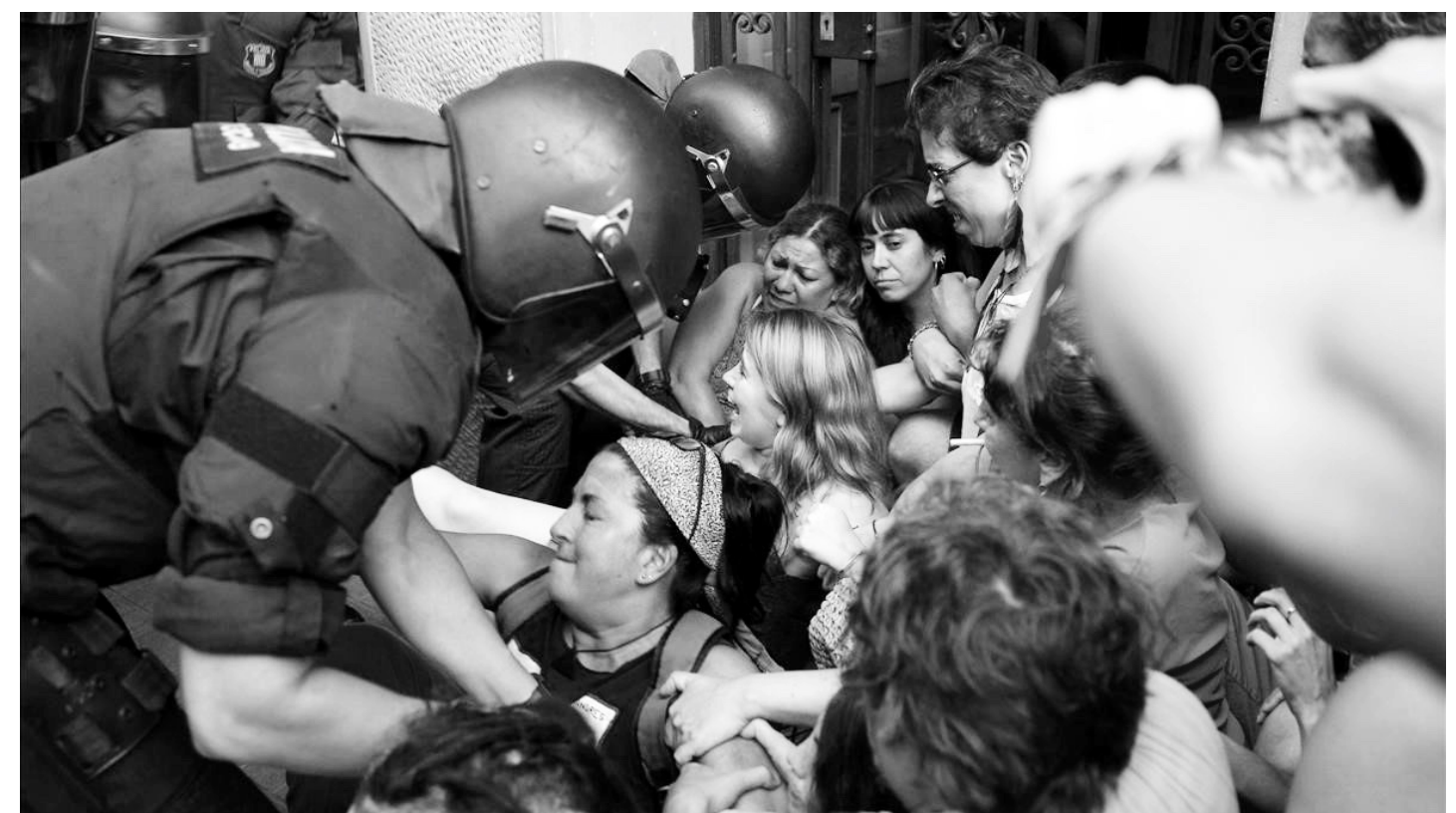

Figure 7. Eviction of several families in the building of 151 Entença Street purchased by an investor. Source: Castán (2017). 
together with the public powers, conscious that younger generations-which are always the basis of the real estate market-could not access mortgage loans, allowed speculation to move to the rental field. In a context in which the demand for rental housing was increasing, the duration of contracts was cut, and eviction was facilitated to ensure that there was greater circulation in the market and that prices would recover much more quickly. To top it off, in 2012, the State decided to give all the tax privileges to the Socimi (BOE, 2012).

Thus, we approach the nature of the new bubble of housing rentals in Barcelona, first discarding that middle classes or wealthy Europeans are that expel those who have less. Likewise, we observe that its most important and least visible power supply is in the incomes of the real-estate financial circuit, which negotiates over each square meter rented. Besides, it is reaffirmed that today the soil of Barcelona, like that of many other cities, is a "safe haven" for international capital and large investment funds. What we are living does not respond to the tale of supply and demand. The public authorities of Barcelona, Catalonia and Spain have long given the green light to the new bubble with laws such as BOE, 2009, 2012 and 2013. Palomera (2015) suggests discarding the myth of an increasingly solvent demand that expels the less affluent habitual residents (gentrification), insofar as what is happening, above all, is a growing strangulation of those who already had difficulty paying the rent. The data do not deceive: the Catalans allocate more than $46 \%$ of the monthly gross salary to pay their rent or mortgage (Sindicat de Llogaters, 2017). And districts such as Ciutat Vella head the list of the most expensive places to rent a home in Spain. Its average price stood, as of October, 2017 , at $€ 19.8 / \mathrm{m}^{2}$ per month (Idealista, 2017). Palomera, in the midst of this, believes that the movement for the right to housing is also being renewed.

The stake of rental housing is then the keystone of the reconstitution of the real estate bubble and its associated elites. This secured a "Barcelona Premium" for global speculators, in addition to the existence of a rental housing stock much higher than the rest of the state $30 \%$ of the total number of houses) and the local hegemony of a rentier bourgeoisie (around the CaixaBank and giants real estate companies like Núñez i Navarro) with powerful international partners (Apilánez, 2017).

\subsubsection{Collaborative Rentism: Airbnb as an Integrator of New Agents in the Real-Estate Financial Circuit}

Multiculturalism in the city centre....The Rambla del Raval is a meeting point to eat and enjoy the street life. Residents of other neighbourhoods come to La Rambla del Raval. In this avenue full of life, modern people, tourists, squatters, street artists, people of Barcelona and souvenir stalls meet....A tourist attraction with a local flavour. (Airbnb, 2017)

This is just a small advertising excerpt (about 100 delights to know in the Barcelona neighbourhoods) that shows how the company exploits (in this case) a central neighbourhood to capture the maximum possible demand of visitors (Figure 8), who, through its platform, temporarily rent private spaces. These are homes that in their great majority were originally planned for the use of habitual

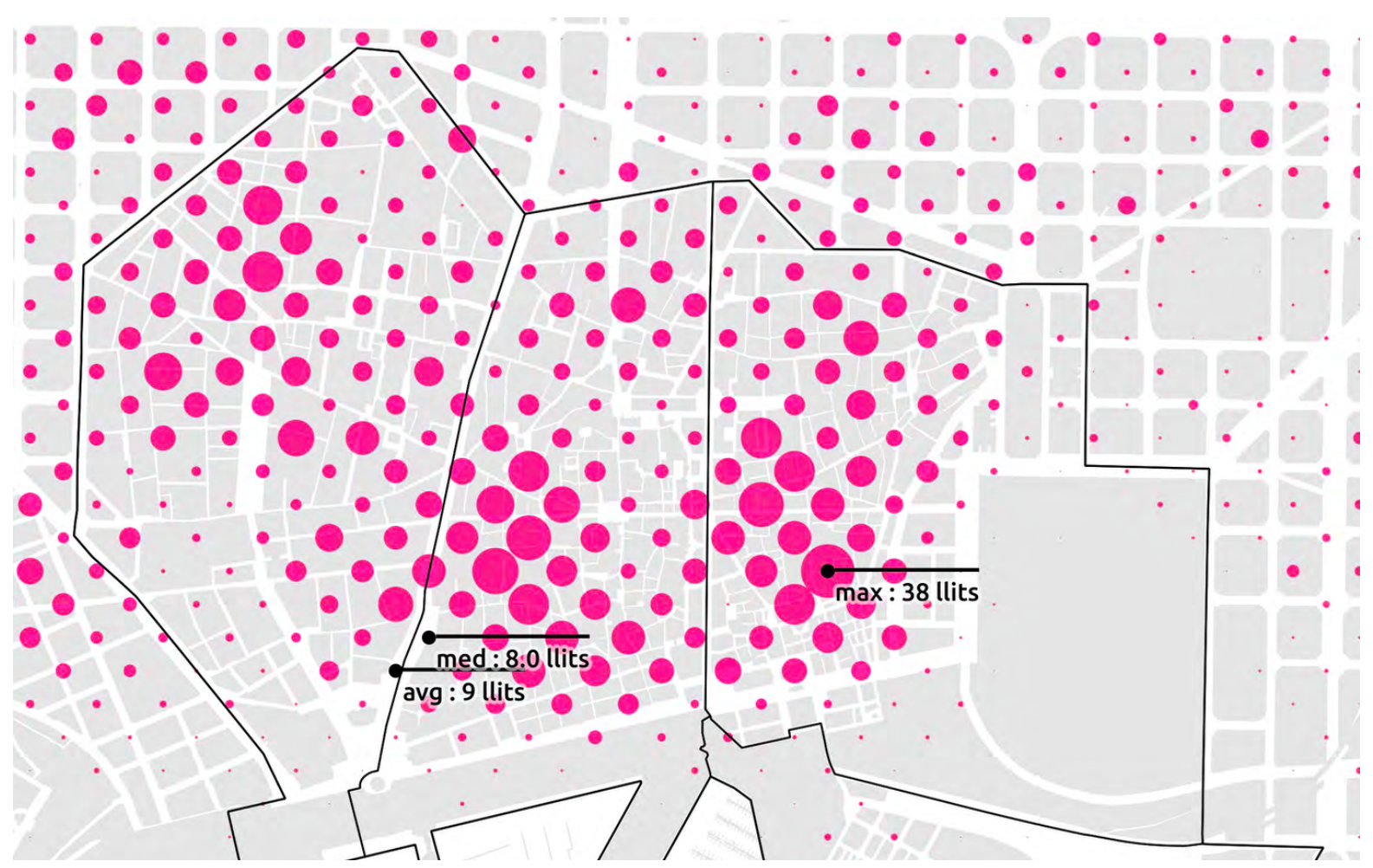

Figure 8. Agglomeration areas of rooms for rent on Airbnb with tourism license. Source: Trescientosmil kms (2017). 
residents. All of which, leaves in evidence his strategy of commodification and globalization of culture, subject to the processes that Harvey and Smith (2005) defined as "the art of rent". It can be verified that this rentism is based on a chain of collaborative efforts between different agents (non-capitalist owners: "hosts", "publicists" and "entrepreneurs" of all kinds of the tourism industry, and users: "guests" seduced to become hosts one day) seeking to make even the presence of "squats" in the space as a collective symbolic capital profitable. Harvey \& Smith (2005) further expanded such a theory of rent to include the collective production of culture as an asset that the market exploits to find new "marks of distinction" for its urban territories. Thus, these new sets of agents (integrated by Airbnb within the real-estate financial circuit) are reproduced, exploiting old and new cultural capital, which has gradually sedimented in a given city (as forms of sociability, quality of life, art production, gastronomic tradition, etc.).

Harvey's essay is one of the few analyses that unveil the political asymmetries that can be found within the much-celebrated cultural commons. Harvey links intangible production and money accumulation not via the regime of intellectual property but as aspects of a parasitic exploitation of the immaterial domain by the material one (Pasquineli, 2014). In this way, collaborative rentism is only another form of real-estate depredation that is contributing, with the strategic exploitation of a collective symbolic capital, to inflating the demand for tourist rentals, and therefore, the new housing rent bubble, with destructive social effects.

\section{The Social Space in the Barcelona Centrality: La Rambla}

Based on the tripartite method of social space analysis, the concepts of Lefebvre are deployed to guide formal, functional and structural analyses. Our objective will be to determine whether or not a transfunctionality is fulfilled and the roles that are assigned to this intermediate unit of social reality. We examine the multiple strategies expressed in the Rambla, around the relations of inhabiting and the use of the boulevard. In this way, the means and instruments of action are established at all levels, linking these strategies to the institutions, agencies and urban agents that operate them. From the tripartite analysis we will present partial conclusions. The formal analysis locates what is perceived in the Rambla within spatial practices. The functional analysis studies the experience of the Rambla as a space of representation, through the images and symbols that accompany it, within the space of centrality. Finally, the structural analysis identifies how the multiple representations in the spatial texture of the Rambla are impregnated with knowledge and ideologies. This analysis allows us to make the link between the whole and the parts. It considers scales, proportions, dimensions and levels, and completes the formal-functional analysis, and does not eliminate them.
With the revival of the neighbourhoods' strength, crushed in the neoliberal era, and agitated since May 2011 in the main Spanish cities, it was possible for the candidacy of Ada Colau to promote from a "decisive space" like Barcelona, "the democratic rebellion" that was needed (Guanyem Barcelona, 2014). Since the first claim was made in the "Manifesto" of the Guanyem Barcelona candidacy, in June 2014, a complex risk was posed when it comes to taking it on. On the one hand, the importance of a "welcoming Barcelona" was recognized, and simultaneously, the candidacy was ready to face the big financial, real estate and tourism lobbies. The specific weight of the attack against the global forces in the campaign speech, without the accompaniment of measures that could be proven effective at that moment, quickly engulfed the aspirations and social energy of people, who generously supported the project at the polls.

To examine in detail the implementation of the Barcelona en Comú project, see Charnock, 2017. In addition, to expand the current critical outlooks on Ciutat Vella District (CVD), it is recommended that the reader review the publications of "masala.cat" (digital newspaper of social denunciation and criticism about (VD), as well as the monograph (8) dedicated to "living in the Historic Centre" of the Urbanism Research Journal (QRU), edited and published by the Urban Planning Department

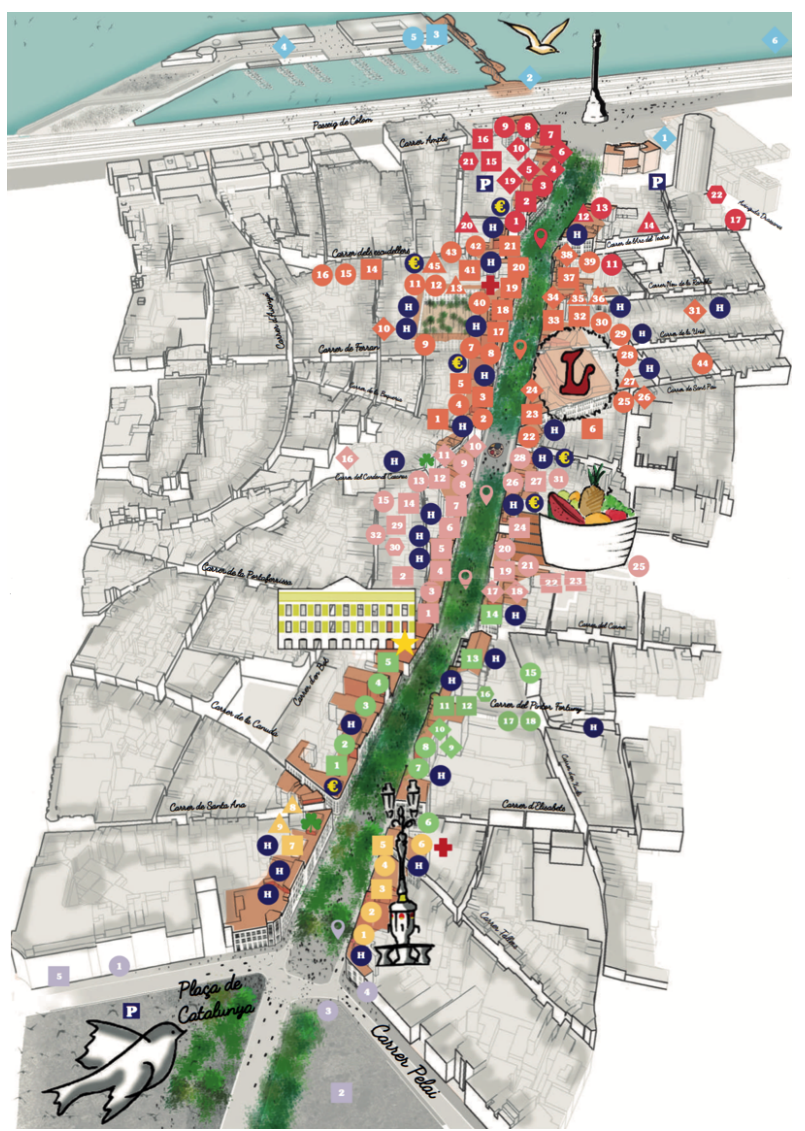

Figure 9. Watercolour drawing in a Rambla guide with its shops. Source: Amics de la Rambla Association (ARA, 2017a). 
(ETSAB-UPC). In this monograph we published a specific article on Ciutat Vella and Lefebvre (see Jiménez Pacheco, 2017a).

\subsection{The Use of the Rambla}

When we think of La Rambla, we have to imagine that every year more than 100 million people (Figure 10) go through it (BCC, 2017). And that along the 1.2-kilometrelong boulevard, there are approximately 1000 registered residents only and more than 200 shops (ARA, 2017a; see also, Figure 9). It is located in the CVD that has 104,000 residents in an area of $4.5 \mathrm{~km}^{2}$ and is one of the most expensive areas to rent a house in Spain (Jiménez Botías, 2017). We have made an observation, participation and quest exam throughout 2017 to identify the speeches, interests, demands, emotions and strategies of the actors directly related to the Rambla (Appendix 4). Due to the extent and diversity of the information collected from primary and secondary sources, we will only explain our partial conclusions.

The processing of the information allowed us to weigh the demanding uses and the power relations that are exercised in the taking of positions on the plans and on-going projects. The question of who gives the orders in La Rambla is cleared. Lefebvre would consider that is capital that commands, primarily, through different systems and superimposed and interconnected flows, with differential weights and impacts on the production of space. To express it in the field, this domination is ob- served with greater brutality in the deployment of the RRC that expels from the city center everything that is not at the level of the localized over-profits of the investors and the Socimi-developers that carry them. Subjected to the RRC, the main power is the commercial capital represented by ARA. From the analysis of strategic positions and alignment of interests, the most "beneficial" arrangement for the RRC is possible between merchants, residents-owners and the BCC. Finally, there is the explosion of the demand for tourists based on the commercialization of the symbolic dimension of the social space, with an enormous weight concentrated on centrality, and a big participation of the tourism industry and the platforms customised to collaborative rentism such as Airbnb. This last phenomenon can be included in the attractiveness of profitability that provides the collective symbolic capital as the engine of a system of production and consumption of leisure space.

\subsection{After the Planners}

In his book After the Planners, Robert Goodman (1972) said that "advocacy planning" and other citizen participation programs can help maintain a mask that allows the poor to manage their own state of dependency, as long as the economic structure is maintained intact and the real power remains constant.

The Urban Uses Plan of Ciutat Vella approved in September 2017, pending the citizens' allegations, reaffirms that Ciutat Vella is an inhabited and dense district.

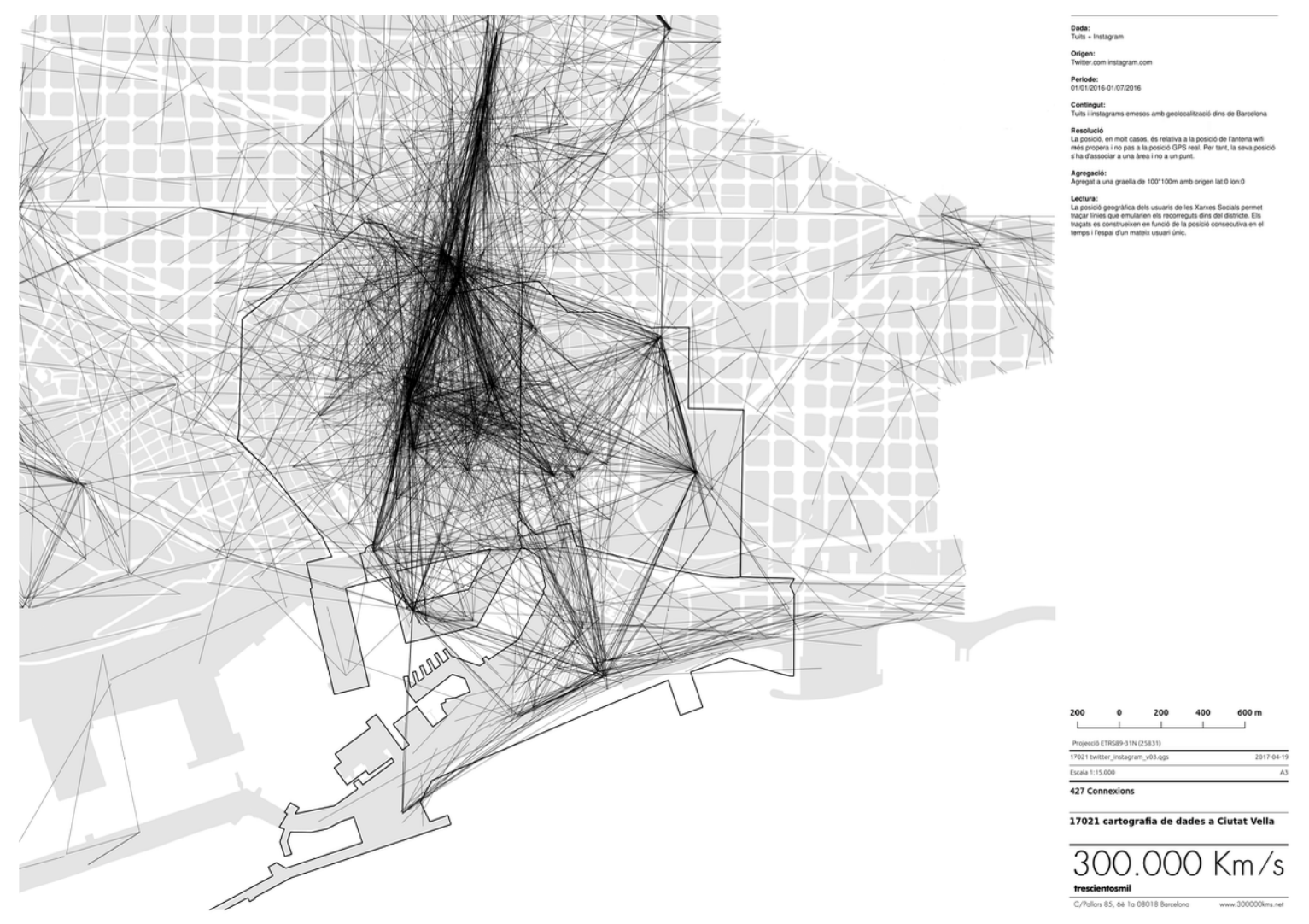

Figure 10. Circuit of people moving in CVD marks La Rambla as main axis of mobility. Source: Trescientosmil kms (2017). 
And its high population density gives it a mainly residential character, which supports that its use of the majority of the land is housing (Figure 11). In this sense, the Plan must guarantee the coexistence between the different urban uses, safeguarding the correct proportion of proximity activities and ensuring that the concentration of public facilities does not cause displacement of other activities that serve the residential mass (CVD, 2017a). The Plan shows that the urban fabric of the district has a fragile morphological condition. This means that on the one hand, the preservation of the characteristics of the urban structure is prioritized, guaranteeing the non-saturation of the public space of the streets; on the other hand, the extreme residential vulnerability of some points of the district makes it unwise for these areas to have a higher burden of establishments, since the inconvenience derived from the activities may have a more harsh impact on the residents.

Thinking about the pedestrians, the Plan regulates where terraces cannot be installed and how the kiosks and bus stops should be arranged to facilitate the permeability of the road. Distances are also stipulated between accesses to public transport and representative buildings catalogued level $A$. With respect to mobility, one of the objectives of the Plan is to pacify the Rambla, prioritizing pedestrian uses, the sponging of elements of the promenade, the efficiency of public transport mobility and the versatility to bind the Raval and Gothic neighborhoods. The BCC will also encourage actions of conservation and improvement of the urban landscape; this includes the promotion of actions for the owners to carry out maintenance and rehabilitation work on the parking lots of buildings (CVD, 2017b).

\subsubsection{Urban Special Planning of the Rambla}

"La Rambla is Barcelona's identity engine but it is a sick engine due to tourism overpressure and the decreasing use by Barcelona residents...its international importance supports the need to protect the heritage" (CVD, 2017a). The Plan definitively approved in May 2016 (Servei de Premsa, 2016) responds fundamentally to the political wills and the correlation of consolidated forces (in the field) before Colau's government. The changes introduced are decorative. It is no coincidence that she has obtained the negative vote of the only anti-capitalist movement in the BCC, the Candidatura d'Unitat Popular. Changes in the dimensions and location of flower and newspaper stands, or the location of bicycle stations, do not address the real problems the District and the promenade suffer, such as the lack of determination of leaving the public access to the roofs of buildings willingness to the owner's communities. The driving idea that covers the Plan is that there is a broad consensus on the need to intervene on the Rambla and recover it for the habitual residents, but the Development Plan does not resolve this. District Councillor Gala Pin has said that "courageous measures" and collaboration between all the actors involved are needed, at institutional, social and, of course, "commercial level" (Servei de Premsa,

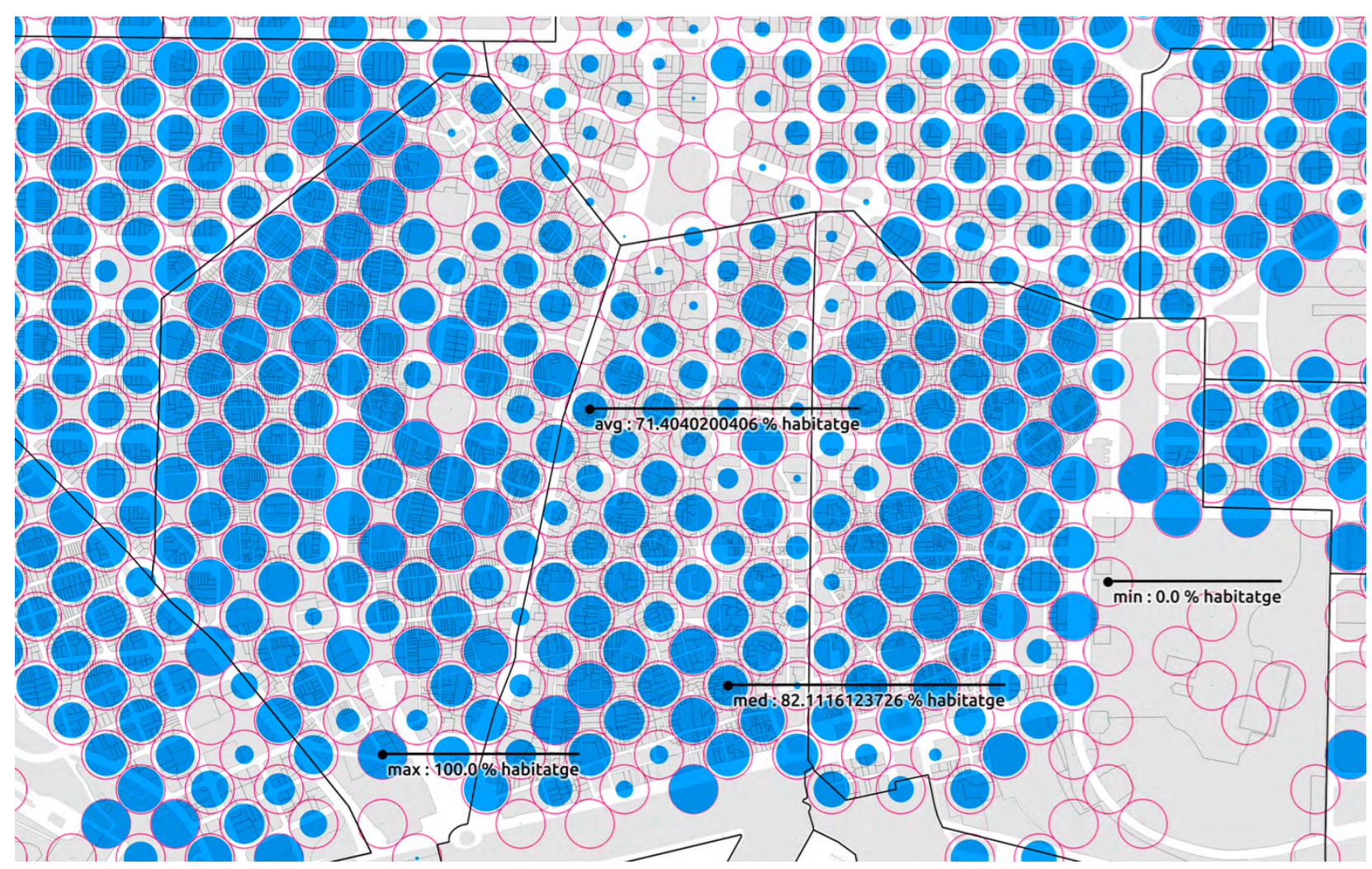

Figure 11. Proportion of housing areas (blue) in relation to other uses (pink) in CVD. Source: Trescientosmil kms (2017). 
2016). The BCC understands that the district has different levels of saturation; it assumes it under various studies in which the count of the establishments total useful area, whether they are of the same type or operating in the same time slot, gives a more adjusted perspective to the real dimension of these activities and their impacts over time (Trescientosmil kms, 2017).

Perhaps more decided was the step taken by the BCC when launching an international contest to prepare the project for La Rambla intervention. We summarize the strategic areas contemplated in the procurement documents: material and immaterial value of the Rambla associated with its habitual residents; trends in existing economic activity; promenade remodeling and reformation works alternatives; relationships and needs with their adjacent neighborhoods; uses for free public space; connections with urban landmarks; unity of the whole; public transport; instruments for social revitalization; ability to attract and functional needs of large equipment; diurnal and nocturnal dynamics; compatible functionalities with an active but respectful public space; mobile dynamics around the existing housing; gender and childhood perspective; monuments and heritage elements (BCC, 2017).

At least eight basic principles contractually posed have to be met in the project development in order that a public space "fulfils the social functions for which it has been prepared" (BCC, 2017). They should be taken as qualitative recommendations that along with a process of citizen participation help in the decision making of the consulting team. The future citizen consultations, the process of design and development of an executive project "should guarantee the application of these principles" (BCC, 2017). We point out the contradictions and the alienation of BCC objectives, for example, if the principle of inclusion aims to have living spaces that favor meetings, on the other hand, the principle of security requires that activities and people influx make meetings difficult and facilitate fluid mobility. Likewise, the principle of accessibility prioritizes pedestrians' seamless movement. So, if the Rambla is not in essence a meeting space, but rather a repeated space of flows, the road towards its neighborhood appropriation becomes more complex. It is striking that the principles of contextualization and mixture are dedicated to giving more weight to the promenade commercial order. We were not surprised to see that the mixture principle is clearly inspired by the requests made by the AAR. Requiring that La Rambla have its own character to differentiate itself from other spaces, and at the same time, adapt to the predominant uses of the spaces that surround it, is to pay for its commercial function.

\subsubsection{Km_Zero Plan for the Rambla Rescue}

As expected, the winning Plan is committed to the municipal strategies. For this reason, what we consider to be the most relevant of the consultant team's propos- als will be recorded on paper. Undoubtedly, the idea of transdisciplinarity is an interesting attempt to address the complexity of the project and its ramifications, as well as the decision to prioritize the social approach, although obviously this does not imply greater scope than the city council's citizenship strategy. The most original is undoubtedly their proposal for a "new culture of administrative-citizen cooperation"; that implies a new methodology and principles to fraternize with citizenship, administration and technical experts. Another important aspect is the participation of activists from SOS Rambla, residents-owners and former officials close to the district in the consultant team. The strategic plan is based on the manifest within the values of citizen participation, transparency, accountability, multidirectional communication and citizen control. To execute it implies co-production and cooperation between administration and citizenship with the use of research-participatoryaction methodological tools to generate spaces for debate and joint production (Km_Zero, 2017).

If there's one thing to be said about urban plans in general, it is that they have the ability to harmonise reality, to hide all traces of urban conflict (Figure 12). We would like to say the urban plans can support conflict management, but in this case, we verify that plans cannot diagnose, much less attack, the real problems. Bearing this in mind, we consider that beyond the useful information that can be lifted, as well as the sophisticated use of analysis tools, the exercise of material and immaterial revaluation of a representational space (within cultural heritage category: contemporary sign of commodification) to rescue the Rambla from tourism exploitation not only does not address the real problems in space but intensifies them. The true appropriation and use by the residents-users of the promenade and centrality (what they call "vecinificación" but empty of content) can only be agitated and promoted from the weakest groups, perhaps hidden under the shadows in the forces correlation. Thus, the design of strategies should demand the construction of another collective subject (now in an emerging state) focused on self-organization. The advisory function weight of "the administrative-citizen management plan" covers with a participatory blanket any possibility of self-management. We take for granted that the impulse (in the form of monitoring) of the administration with its egalitarian citizenship will leave out the energy and the desires of the working and popular classes, and at best, it will end up co-opting them.

\section{The Production of Radical Social Space in Barcelona}

Any attempt to realize a truly social urban plan is truly impossible within the framework of capitalist society (M. Tatjer, in Delgado, 2017).

Once Lefebvrian thought has guided us to this point, we now ask ourselves how it is completed, updated and deepened, so that it helps us to counter the RRC with decisiveness and efficiency, and also, how to reconnect 


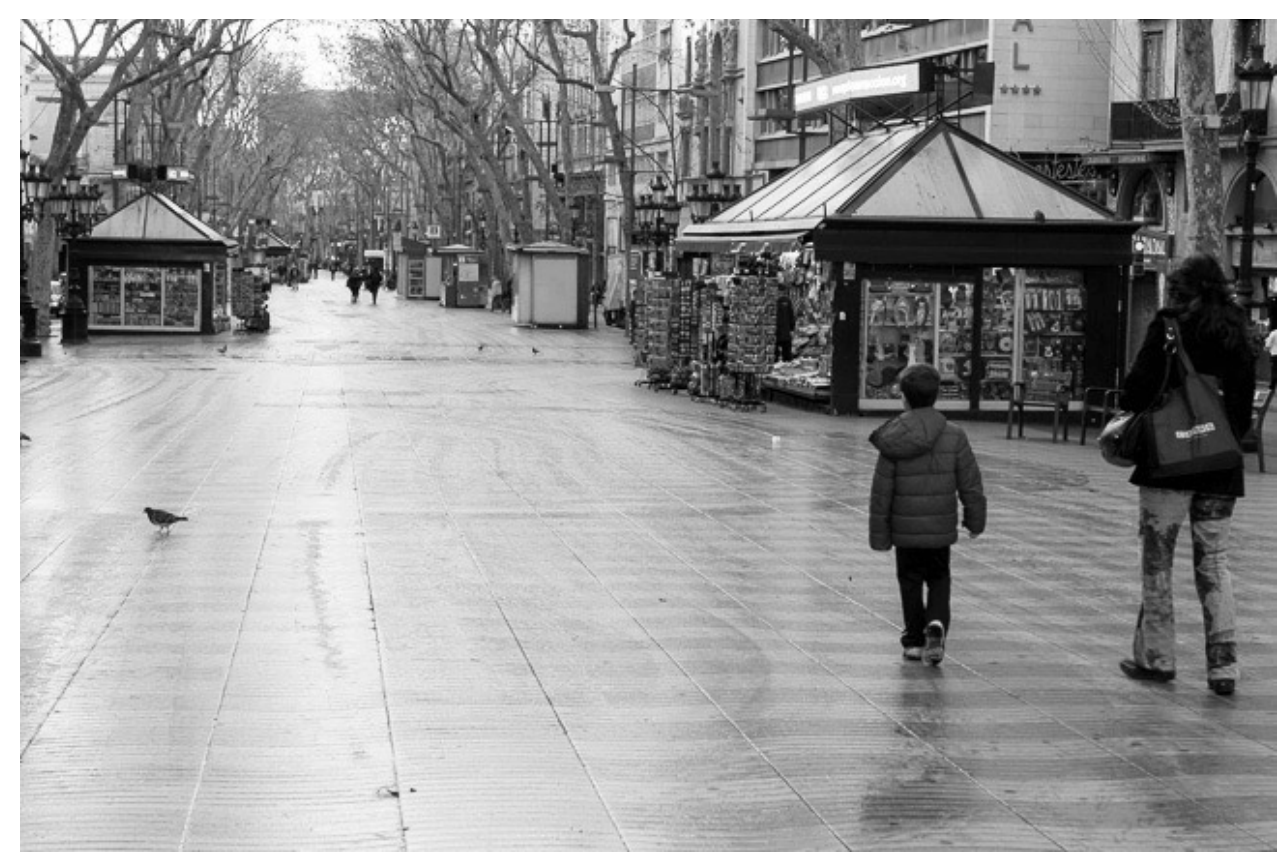

Figure 12. Does the Rambla of the future exist, maybe just an early Sunday morning? Source: Barcelona Experience (2017).

with social movements, since the battle to fight against capitalist urbanization is not only theoretical (Figure 13). Faced with the overwhelming global urban reality that weighs on Barcelona, what are the possibilities of building an effective popular resistance against real estate violence? What can we do from the urban plans and politics of space to update the right to the city in the real battle being waged in Barcelona? And how to include in that concept the sabotage of the RRC, trying to go beyond the limits of the reproduction of the relations of capitalist production (Lefebvre, 1971) in space?

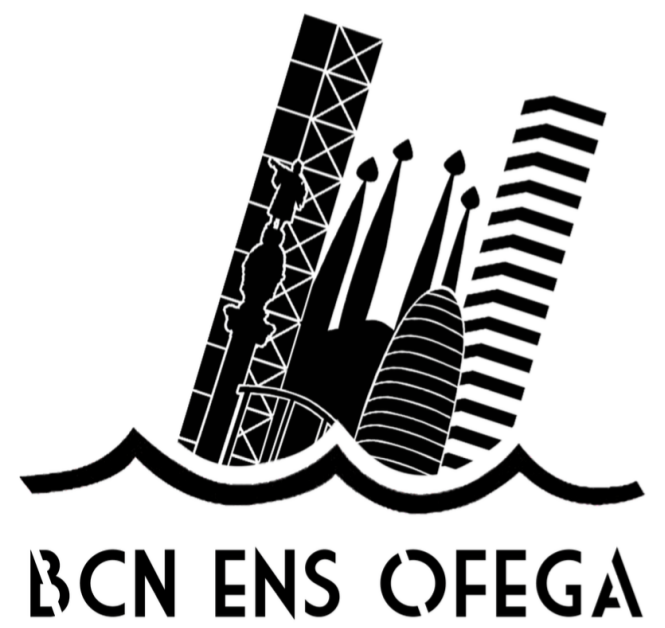

Figure 13. Campaigns against the city commodification and "Barcelona brand". Source: Bcn Ens Ofega (2016) and SOS Rambla (2017).
The notion of radical social space transcends a concrete object when it becomes strategic for action. This signal implies that the new urban policies have to facilitate alternative forms of anti-capitalist response and resistance that allow society to reveal itself against the social relations of production embodied in the transition to post-neoliberal urban systems (Jiménez Pacheco, 2016b, 2017b). The phenomenon designated as "turistification" is not the problem to be fought precisely, given that the real problem is capitalism. Harvey (2016) in his conference talk in Barcelona on "the tourist city" reinforced

\section{BARGELONA NO ESTLA EN VEIDA}
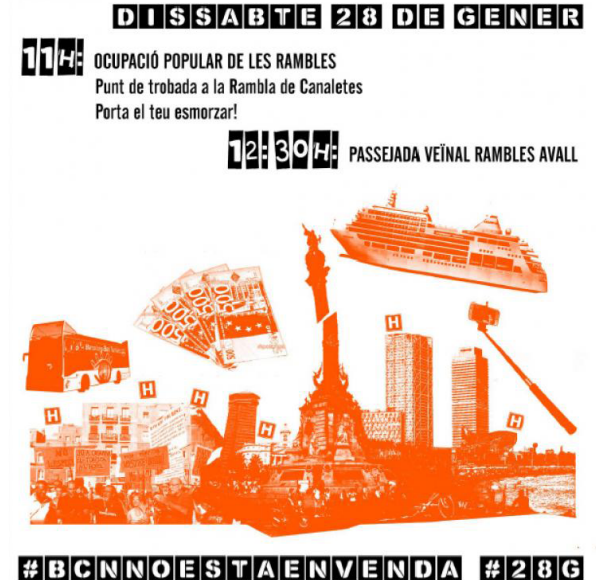
Lefebvre's (1978/2017) proposal, in which a "global anticapitalist project" is required to advocate for "another society in another space".

\section{1. (De Facto) Right to the City}

It is necessary to take a thesis shared by A. Apilánez (2017) and M. Delgado (2017), synthesized in that the legalist-reformist way cannot tame the beast of capital. Apilánez (2017) criticizes a genealogy of organizations of "15-Mayist tradition" that have become protagonists of the social response to the most dramatic effects of the real estate collapse, characterized by the adoption of a strategy based on the reduction of damage and the proposal of legislative reforms. Its justification of the moderation of such measures always acquires tactical signs, based on prudence and adaptation to bad times (Apilánez, 2017). Meanwhile, the avalanche of a structural problem goes beyond the "municipalities of change and democratic regeneration" (Guanyem Barcelona, 2014), which recognizes in a masked way its impotence to face it. The definitive criticism of Delgado (in a recent interview) is clarified, when linking the management of mayors-Porcioles, Maragall and now Colau-in his task of administering the catastrophic consequences of a city concept based on the enrichment of companies that extract benefits from the converted city in merchandise (Aricó, Mansilla, \& Stanchieri, 2016; Jiménez Pacheco, 2017a), which means, currently, that Ada Colau, worldwide, ends up symbolizing the possibility of a capitalism with a human face. "This is a lie...because finally the beast can not be tamed" (Delgado, 2017, p. 13).

In November 2017 in Paris, the International Colloquium "Right to the city in the south, urban experiences and rationalities of government" took place. Its main purpose was to understand the relationships between the everyday practices of city dwellers and governmental rationalities. It raised the framework of the "De Facto right to the city" designating a social and spatial ordering process that emerges from the interactions between public action and everyday practices when establishing themselves as routine (University Paris Diderot, 2017). The problem for us was that, given certain conditions, this "Right" involved considering urban practices in their conformist dimensions, understood not as the result of open political conflicts but as a process of adjustment between urban experiences and the normative production of systemic rationalities. From there, we perceive its correspondence with the post-neoliberal and citizen theories of urban pacification and civic adaptation promoted by BCC. This encouraged us to return radicality to the "De Facto Right" of people without rights, in which institutions would be, first of all, obliged to understand and adapt to certain insurgent/emancipatory situations (e.g., La Ingobernable, 2017; Sindicato de Inquilinas de Gran Canaria, 2017). The Canary Syndicate advocates the defense of "illegalism" as a principle of action, accom- panied, when necessary, by tactical recourse to legality and to institutional resources as mechanisms to take advantage of the guarantor side of the legislation of modern "democracy" (Apilánez, 2017). Lefebvre himself reminds us the Spanish struggles in 1977, when he said that more than 4,000 resident committees carried out an activity that questions the society organization together with cities and space: "[t]hese movements renew the concept of 'use' without reducing it to a simple consumption of space; [they] emphasize people relationships (individuals, groups, classes) in space with its levels" (Lefebvre, 2017, p. 6).

On the future of this right, Merrifield (2017) reminds us that Lefebvre was a man of the margins. His right to the city was an ideal conceived from the periphery. His goal was to empower outsiders to enter. The right to the city (Lefebvre, 1969) may seem like a kind of fuzzy human right, but it is very concrete: "[i]t means that you feel some sense of collective, shared purpose, that you're not alienated from the city's affairs". Lefebvre also observed how "professional democracy" reproduces its own management and domination customs. That's why he thought that a new vision was required, a new kind of citizenship and belonging (the old right to the city was no longer enough). Lefebvre (1989) affirmed that the right to the city implies nothing less than a revolutionary conception of citizenship.

The planetary urbanization with its totalizing power rejects and expels everything that does not serve it, producing what Lefebvre called a "residue". Waste is people who feel the periphery within them, even if they are sometimes in the core. Residues are people who feel the periphery inside them, even if sometimes they're located in the core. The Rambla and downtown Barcelona also congregate residues:

Precarious and downsized workers, informal and gig economy workers, workers without regularity, without salaries, without benefits and pensions. Residues are refugees rejected and rebuked, profiled and patrolled no matter where they roam. They're people forced off the land, thrown out of their homes by impersonal property markets and violent eviction. (Merrifield, 2017)

The right to urban centrality is now about those who have been expelled-the residues-who claim for the first time their right to a collective urban life, to an urban society that they are actively creating and in which they have been so far deprived of their rights. Under this appearance, citizenship is found inside and beyond a passport, inside and beyond any official documentation. This is the case of the "Top Manta" (Figure 14) in Barcelona: undocumented migrants who sell products spread out on a blanket on city streets (ARA, 2017b; Aricó \& Mansilla, 2016; Calvó \& França, 2017). The "citizens of the shadows" are the new norm, the new global predetermined position. Therefore, residues are now not merely 


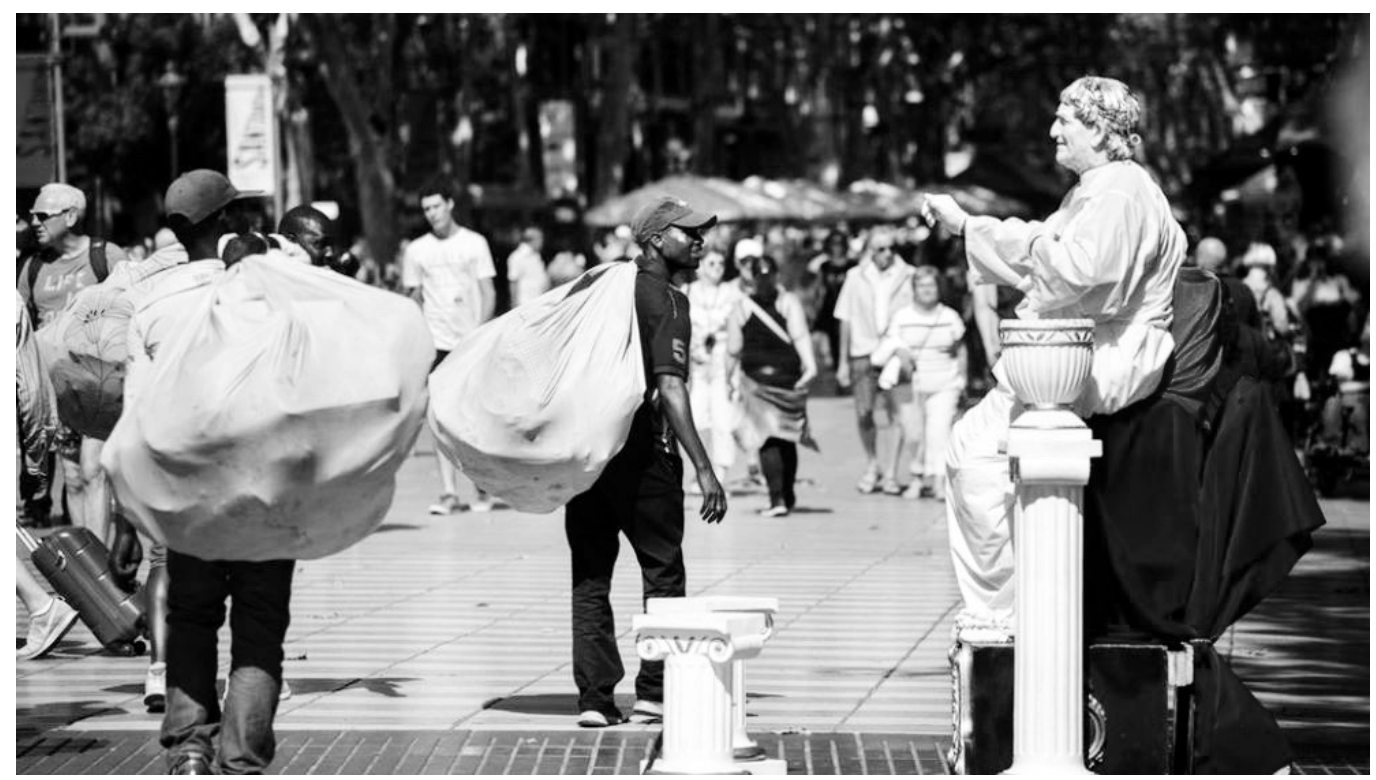

Figure 14. Everyday uses of La Rambla. "Mantas en el centro”. Source: La Vanguardia (2015).

the secretion of the city, but the very substance of the city itself. The "de facto right to the city" can help us create new forms of organization and above all that new revolutionary citizenship.

\section{Conclusions}

We have several reasons to consider that the Lefebvrian critical theoretical apparatus, especially the deepening in its theory and methods of social space analysis-used in this article-is extremely useful for the critical analysis of the global contemporary city in the scope of what we consider the real battle against capitalist urbanization. First, Lefebvre's method, while guiding the process and design of research, not being a closed system, creates the breach for a methodological plurality of transdisciplinary orientation, without this undermining the empirical rigor of research. Thus, the levels and dimensions, crossed with the classifications proposed by Lefebvre, allow us to establish a critical theoretical link between the emergence of the real-estate financial circuit, the social space devastation and political power relationships inside and outside technocracy. On the other hand, the epistemological (of his thought treated as a whole in his theory of social space) and the genealogical contents (belonging to a "Lefebvrian tradition") are effectively confronted with the complexity of the current reality of Barcelona, demonstrating the pedagogical instrumentality of case study. Thirdly, the exposition of the analysis has been able to lead, under the tutelage of Lefebvre himself, to a "globalizing" discourse of local struggles to exercise the right to the production of radical social space; there, where the most difficult urban problematic does not exist, or is omitted, much less solved with municipal planning, while political will (despite its reformist scheme) is contradictory or simply fragile. Finally, we must recognize the problems-derived from the treatment of Lefeb- vre's thought as a non-fragmented project-for sizing the article (in which we know that everything will never fit). However, having taken the necessary precautions, we can share the effectiveness of the Lefebvrian matrix and the experience of Barcelona to entrust it to the analysis of other urban realities under capitalist violence.

\section{Acknowledgements}

This research has been supported by the Secretaría de Educación Superior, Ciencia, Tecnología e Innovación (SENESCYT)-Ecuador.

\section{Conflict of Interests}

The authors declare no conflict of interests.

\section{References}

Airbnb. (2017). El Raval: Guía de Barcelona. Vecindarios de Airbnb. Retrieved from https://www.airbnb.es

Ahorro Corporación Financiera. (2016). Nuevas Socimis centradas en la vivienda residencial cotizarán en el MAB. Consenso del Mercado. Retrieved from http:// consensodelmercado.com

Apilánez, A. (2017). La verdadera batalla por Barcelona. Trampantojos y Embelecos. Retrieved from www. trampantojosyembelecos.wordpress.com

ARA. (2017a). Introducció. Amics de la Rambla. Retrieved from https://www.amicsdelarambla.cat

ARA. (2017b). La ciutat diu prou al Top Manta. Amics de la Rambla. Retrieved from https://www.amics delarambla.cat

Aricó, G., \& Mansilla, J. (2016). De manteros y skates u otros surrealismos urbanos. Observatori d'Antropologia del Conflicte Urbà. Retrieved from https://observatoriconflicteurba.org 
Aricó, G., Mansilla, J., \& Stanchieri, M. (2016). El legado Porciolista (Working Paper number 4-505, presented at the Congresso Internacional Contested_Cities). Madrid: Universidad Autónoma de Madrid. Retrieved from http://contested-cities.net/wp-content /uploads/sites/8/2016/07/WPCC-164505-Aric\%C3\% B3MasillaStanchieri-LegadoPorciolista.pdf

Barciela, F. (2016). ¿Volverán a repuntar las Socimi? Todos dicen que si. Consenso del Mercado. Retrieved from http://consensodelmercado.com

Barciela, F. (2017). Las Socimis españolas viven un 'boom' sin paragón en Europa. Consenso del Mercado. Retrieved from http://consensodelmercado.com

Barcelona Experience. (2017). Book one of our early bird Barcelona bike tours. Barcelona Experience. Retrieved from https://www.barcelonaexperience.com

BCC. (2017). Rambla Segle XXI. Serveis relatius a la redacció d'estratègies d'actuació i projecte d'urbanització de La Rambla. Barcelona: BCC.

Bcn Ens Ofega. (2016). Stamp posting campaign (stencil). Bcn Ens Ofega. Retrieved from https:// bcnensofega.wordpress.com

Benito de Vega, J. (2017, March). Axiare, la Socimi cotizada que ha creado mayor valor para el accionista. Consenso del Mercado. Retrieved from http:// consensodelmercado.com

BOE. (2009). Ley por la que se regulan las Sociedades Anónimas Cotizadas de Inversión en el Mercado Inmobiliario (Ley 11/2009). Madrid: Gobierno de España.

BOE. (2012). Ley por la que se adoptan diversas medidas tributarias dirigidas a la consolidación de las finanzas públicas y al impulso de la actividad económica (Ley 16/2012). Madrid: Gobierno de España.

BOE. (2013, June 4). Ley de medidas de flexibilización y fomento del mercado del alquiler de viviendas (Ley 4/2013). Madrid: Gobierno de España.

Calvó, S., \& França, J. (2017). Plegar la manta, en 30 minutos. Barcelona: TV3. Retrieved from http://www. ccma.cat/tv3/30-minuts/plegar-la-manta/noticia/28 23159

Castán, P. (2017). Polémica desocupación policial en un símbolo de la gentrificación. El Periódico. Retrieved from http://www.elperiodico.com

Charnock, G., Purcell, T., \& Ribera-Fumaz, R. (2014). City of rents. The limits to the Barcelona model of urban competitiveness. International Journal of Urban and Regional Research, 38(1), 198-217.

Charnock, G. (2017). Barcelona en Comú, urban democracy and the common good. Socialist Register, 54, 188-201.

CVD. (2017a). Pla d'usos de Ciutat Vella. Barcelona: BBC.

CVD. (2017b). Memòria del estudi dels usos urbans a Ciutat Vella, tipus i conflictes. Barcelona: BCC.

Delgado, M. (2017). Los movimientos sociales ahora no están volvemos a la catástrofe de la Transición. Carrer, 2017(145/146), p. 13.

Díaz, C. (2016). El ladrillo se beneficia de la baja rentabil- idad de la renta fija y de los depósitos bancarios. Consenso del Mercado. Retrieved from http:// consensodelmercado.com

Goodman, R. (1972). After the Planners. Harmondsworth: Penguin Books.

Gottdiener, M. (2000). Lefebvre and the bias of academic urbanism. CITY, 4(1), 93-100.

Guanyem Barcelona. (2014). Manifiesto. Barcelona en Comu. Retrieved from https://barcelonaencomu.cat

Harvey, D., \& Smith, N. (2005). Capital financiero, propiedad inmobiliaria y cultura. Barcelona: Universidad Autónoma de Barcelona.

Harvey, D. (2014). Urbanismo y desigualdad social. Madrid: Siglo XXI. (Original work published 1973)

Harvey, D. (2016). Culture and city: The challenge of tourism. Barcelona: CCCB.

Idealista. (2015). El español ha perdido un $25 \%$ de su salario real desde 2007, mientras el alemán ha ganado un 5\%. Idealista. Retrieved from https:// www.idealista.com

Idealista. (2017). Los distritos de Madrid y Barcelona donde el precio del alquiler marcó máximos en verano. Idealista. Retrieved from https://www. idealista.com

IMV. (2017). XXV Informe sobre el mercado de la vivienda. Barcelona: Tecnocasa \& UPF.

Jiménez Botías, M. (2017). Barcelona es la ciudad española con los alquileres más caros. El Periódico. Retrieved from http://www.elperiodico.com/es

Jiménez Pacheco, P. (2015). Epistemological clues to figure out the right to the city of Henri Lefebvre. ESTOA, 8, 5-13.

Jiménez Pacheco, P. (2016a). Introducción al espacio radical humano: Tres momentos de creación en Henri Lefebvre para anticipar su noción. In Universitat Politècnica de Catalunya (Ed.), Actas del VIII Seminario Internacional de Investigación en Urbanismo (pp. 1-14). Barcelona: Universitat Politècnica de Catalunya.

Jiménez Pacheco, P. (2016b). Fundamentos del espacio radical humano. Función epistemológica de un objeto posible al servicio de la transformación de la vida y la resistencia urbana. (Working Paper presented at the Congresso Internacional Contested_Cities). Madrid: Universidad Autónoma de Madrid.

Jiménez Pacheco, P. (2017a). Re-imaginar el centro para cambiar la vida. Ciutat Vella como obra del habitar a través del pensamiento de Henri Lefebvre. $Q R U, 8$, 80-96.

Jiménez Pacheco, P. (2017b). Henri Lefebvre's social space: Towards the production of human radical space (theory and politics). Paper presented at the RC21 Leeds Conference for Rethinking Urban Global Justice, Leeds, England.

Km_Zero. (2017). Les Rambles. Barcelona: BCC.

La Ingobernable. (2017). Nosotras. Ingobernable. Retrieved from https://ingobernable.net

La Vanguardia. (2015). Barcelona se convierte en el gran 
bazar mantero de Europa. La Vanguardia. Retrieved from http://www.lavanguardia.com/

Lefebvre, H. (1969). El derecho a la ciudad. Barcelona: Península.

Lefebvre, H. (1971). La re-production des rapports de production. L'Homme et la société, 22, 3-23.

Lefebvre, H. (1972a). La revolución urbana. Madrid: Alianza. (Original work published 1970)

Lefebvre, H. (1972b). Hacia el cibernántropo (contra los tecnócratas). Buenos Aires: Granica. (Original work published 1967)

Lefebvre, H. (1983). El pensamiento marxista y la ciudad. Madrid: Universidad Politécnica de Madrid. (Original work published 1972)

Lefebvre, H. (1989). Dissolving city, planetary metamorphosis (N. Brenner, Trans.). Society and Space, 32, 203-205.

Lefebvre, H. (1991). The production of space. Blackwell: Oxford. (Original work published 1974)

Lefebvre, H. (2017). El espacio y el Estado (P. Jiménez Pacheco, Trans.). Paris: Union Générale d’Editions. Retrieved from https://marxismocritico.com/2017/ 09/08/el-espacio-y-el-estado (Original work published 1978)

López, I., \& Rodríguez, E. (2013). Competitividad territorial y circuito secundario de acumulación. El paroxismo de un caso: El ciclo español de 1995-2007. In OMM (Ed.), Paisajes devastados después del ciclo inmobiliario: Impactos regionales y urbanos de la crisis (pp. 25-72). Madrid: Traficante de Sueños.

Marx, K. (1977). Crítica del programa de Gotha. Moscow: Editorial Progreso. (Original work published 1875)

Merrifield, A. (2017). Fifty years on: The right to the city. In Verso (Ed.), The right to the city. A Verso report (pp. 18-32). London: Verso.
Ortega, M. (2017). En defensa del llogater. Amics de la Rambla. Retrieved from https://www.ara.cat

Palomera, J. (2015). The political economy of Spain. A brief history (1939-2014). Barcelona: Proyecto Greco ERC.

Pasquineli, M. (2014). The sabotage of rent. Censura, 1, 162-173.

Servei de Premsa. (2016). L'ajuntament de Barcelona aprova definitivament el Pla especial d'ordenació de la Rambla. Barcelona: BCC.

Servei de Premsa. (2017). L'ajuntament de Barcelona convoca un concurs internacional per a la transformació de la Rambla. Barcelona: BCC.

Sindicat de Llogaters. (2017). Manifiesto. Sindicat de Llogaters. Retrieved from https://sindicatdellogateres. org/es

Sindicato de Inquilinas de Gran Canaria. (2017). Principios. Retrieved from https://sindicatodeinquilinasgc. noblogs.org

SOS Rambla. (2017). Convocatòria a l'ocupació popular de la Rambla (Flyer). CGT Barcelona. Retrieved from http://www.cgtbarcelona.org

Topalov, C. (1978). La urbanización capitalista, algunos elementos para su análisis (1st ed.). México: Edicol.

Tramullas, M. (2017). La vivienda usada sube un 7,37\% gracias a los inversores, que ya son el $28 \%$ de los compradores. Consenso del Mercado. Retrieved from http://consensodelmercado.com

Trescientosmil kms. (2017). Cartografia de dades a Ciutat Vella. Barcelona: BCC.

University Paris Diderot. (2017). The right to the city in the South, everyday urban experience and rationalities of government. Paris: Cessma. Retrieved from http://dalvaa.hypotheses.org

\section{About the Author}

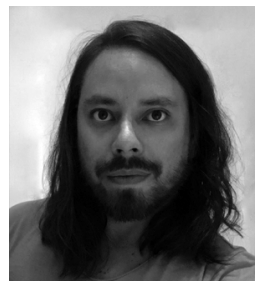

Pedro Jiménez Pacheco is a PhD candidate in Theory and History of Architecture in the Barcelona School of Architecture at the Polytechnic University of Catalonia. He has a grant from the Ecuadorian Government and is Member of the RC21 Urban and Regional Development. His dissertation focuses on updating and deepening the radical social space theory and Henri Lefebvre's urban criticism applied in the center-periphery analysis of Barcelona under mayor Ada Colau administration. His research fields are critical urban theory and social space policy. He collaborates with several research networks of urban conflict in Spain and the Marxismo Crítico website. 


\section{Appendices}

\section{Appendix 1}

"Centrality" corresponds to the formal category used by Lefebvre for the analysis of a specific urban phenomenon; while, his notion of center covers a general concept-more broad-in the study of urban space-time (Lefebvre, 1970/1972a).

\section{Appendix 2}

Lefebvre explains the theoretical category of "level" in 1961 in the second volume of his Critique of Everyday Life. A level designates an aspect of reality, but it is not just the equivalent of a camera shot of that reality. It allows for it to be seen from a certain point of view or perspective; it guarantees it an objective content. In a reality where successive implications can be seen, it represents a degree or a stage, but with more consistency and "reality" than symbols or models, for example. Levels cannot be completely dissociated from one another. Analysis may determine levels, but it does not produce them; they remain as units within a larger whole. The schematic of a scale or of a formal hierarchy of degrees is much too static (Lefebvre, 2014).

\section{Appendix 3}

To clearly observe the dominant spatial-production-mode in Barcelona, we first had to clear several interferences away, taken into account at the beginning in an intuitive way. For example, the terrible interferences of the conflict between constitutionalists and separatists in 2017 led, to a great extent, to the desire for citizen participation to result in decisions being made based on spurious political pacts. In August of 2017, the problem of urban security moved center-stage after the heart of the city (La Rambla) was the scene of a terrorist attack that left dozens dead and a little more than a hundred injured-of 34 different nationalities. Also, several sentences were handed down in cases of corruption (involving business networks that diverted funds in urban and infrastructure contracts) in relation to the administration of the Palau de la Música. Finally, a current of journalistic agitation reappeared with the scandals of the "narcopisos" in the city and the mafias associated with housing in the hands of squatters. Often, politicians to sow their populist strategy exploit this agitation.

\section{Appendix 4}

a) February 24, 2017: "From the Rambla to see, on the Rambla to live", debate organized by Col-legi d'Arquitectes de Catalunya. Interviews conducted: Eduard Elias, spokesman of the SOS Rambla Association, and Gala Pin, Ciutat Vella District Councillor; the opinions of 50 habitual residents of ownership unknown were gathered.

b) March 17, 2017: Walk along La Rambla with City Council technicians; competition participants for La Rambla transformation and local residents. Interviews conducted: Alejandro Jiménez, spokesman of the La Ravala Association, and Libia Colomina, local resident-owner.

c) April 18, 2017: "Vecinos de la Rambla, una especie en extinction": Francisc Manzano interviews Anna Montané and Maria Luisa Paytubi, local resident-owners (Betevé, 2017).

d) September 5, 2017: Interviews: Mònica Trias, President of the Antics Ocellaires de La Rambla Association, Vicente Guallart, local resident-owner, and Fermí Villar, President of ARA.

e) Memòria del procés participatiu de Pla d'usos de Ciutat Vella (CVD, 2017c). 
U COGITATIO

Appendix 5

Lefebvrian matrix (grid unfolded) for social space analysis in the Barcelona centrality:

\begin{tabular}{|c|c|c|c|c|c|c|c|c|c|c|c|}
\hline \multirow[b]{2}{*}{$\begin{array}{l}\text { Soc } \\
\text { spa }\end{array}$} & \multicolumn{3}{|c|}{ URBAN PHENOMENON PROPERTIES } & \multicolumn{3}{|c|}{ SCIENCE OF THE USE OF SPACE } & \multicolumn{3}{|c|}{ SEMANTIC DIMENSIONS OF URBAN SPACE } & \multirow[b]{2}{*}{ USE } & \multirow[b]{2}{*}{ CONTENT } \\
\hline & $\begin{array}{l}\text { Projection of } \\
\text { social relations }\end{array}$ & $\begin{array}{l}\text { Confrontation } \\
\text { of strategies }\end{array}$ & $\begin{array}{l}\text { Urban } \\
\text { practices }\end{array}$ & Formal Analysis & Functional Analysis & Structural Analysis & Paradigmatic & Syntagmatic & Symbolic & & \\
\hline \multirow{2}{*}{ 总 } & $\begin{array}{l}\text { Land-ownership; } \\
\text { Real-estate } \\
\text { market; } \\
\text { Sociability } \\
\text { relationships }\end{array}$ & $\begin{array}{l}\text { Associations of } \\
\text { neighbors; } \\
\text { squatters; building } \\
\text { managers; family } \\
\text { groups; } \\
\text { individuals; etc. }\end{array}$ & $\begin{array}{l}\text { Moments of } \\
\text { sleep } \\
\text { hunger, } \\
\text { housework, } \\
\text { sexuality, } \\
\text { study, rest, } \\
\text { etc. }\end{array}$ & $\begin{array}{l}\text { Places of habitation } \\
\text { are distinguished in } \\
\text { public (portal, } \\
\text { entrance, hallway } \\
\text { etc.) semipublic (hall } \\
\text { of yesterday, current } \\
\text { living room) and } \\
\text { private (rooms, } \\
\text { bathrooms, etc). They } \\
\text { can also be classified } \\
\text { as they are dedicated } \\
\text { to the passage, stay, } \\
\text { and meeting. As well } \\
\text { as services (Places } \\
\text { that serve actively; } \\
\text { Places served } \\
\text { passively). }\end{array}$ & $\begin{array}{l}\text { it is possible to } \\
\text { enumerate the } \\
\text { functions inherent in } \\
\text { inhabiting that } \\
\text { correspond (or not) } \\
\text { to urban and social } \\
\text { functions governed } \\
\text { by the social division } \\
\text { of labor, at the level } \\
\text { of agglomeration or } \\
\text { society. Work and } \\
\text { relaxation; food and } \\
\text { reception; } \\
\text { reservation and } \\
\text { evacuation; meeting } \\
\text { and communication; } \\
\text { etc. }\end{array}$ & $\begin{array}{l}\text { Essentially paths } \\
\text { that link in every } \\
\text { possible way the } \\
\text { distinguished and } \\
\text { articulated places. } \\
\text { establishes the list } \\
\text { of sequences, } \\
\text { linking the topic of } \\
\text { habiting of the more } \\
\text { general topologies } \\
\text { of urban space and } \\
\text { social space, and } \\
\text { consequently to } \\
\text { urban phenomena } \\
\text { and to the } \\
\text { organization of the } \\
\text { city. }\end{array}$ & $\begin{array}{l}\text { In-out; high-low; } \\
\text { domination- } \\
\text { appropriation } \\
\text { public-private } \\
\text { mobile-fixed; } \\
\text { central-peripheral; } \\
\text { demarcated- } \\
\text { oriented; use- } \\
\text { change. }\end{array}$ & $\begin{array}{l}\text { Internal; } \\
\text { external; } \\
\text { transitional; } \\
\text { circulation. }\end{array}$ & $\begin{array}{l}\text { Family; } \\
\text { love; } \\
\text { fertility; the } \\
\text { sacred; } \\
\text { marriage; } \\
\text { patriarchal } \\
\text { etc. }\end{array}$ & $\begin{array}{l}\text { Everyday } \\
\text { time; } \\
\text { individual } \\
\text { vitality; } \\
\text { immediate } \\
\text { use. }\end{array}$ & $\begin{array}{l}\text { Houses; } \\
\text { apartments; } \\
\text { habitation } \\
\text { spaces; etc. }\end{array}$ \\
\hline & $\begin{array}{l}\text { Reproduction of } \\
\text { the relations of } \\
\text { production; } \\
\text { Real-estate } \\
\text { market; } \\
\text { Sociability } \\
\text { relationships; } \\
\text { Labor market; } \\
\text { Tertiary, cultural } \\
\text { and touristic } \\
\text { sector markets; } \\
\text { Collaborative, } \\
\text { innovation and } \\
\text { knowledge, } \\
\text { technological } \\
\text { markets (smart } \\
\text { city, startups). }\end{array}$ & $\begin{array}{l}\text { Associations in } \\
\text { general; parish } \\
\text { councils; } \\
\text { collectives; } \\
\text { private } \\
\text { institutions; trade } \\
\text { union and } \\
\text { productive } \\
\text { representatives; } \\
\text { professional } \\
\text { colleges; media; } \\
\text { municipalities; } \\
\text { councilors; } \\
\text { academics; etc. }\end{array}$ & $\begin{array}{l}\text { Multiplicity } \\
\text { of moments } \\
\text { (expressed in } \\
\text { the misery } \\
\text { and } \\
\text { greatness of } \\
\text { everyday life, } \\
\text { including } \\
\text { boredom and } \\
\text { enjoyment). }\end{array}$ & $\begin{array}{l}\text { Encounter } \\
\text { concentration and } \\
\text { simultaneity places; } \\
\text { near and distant } \\
\text { environment. }\end{array}$ & $\begin{array}{l}\text { Means and } \\
\text { mediation }\end{array}$ & $\begin{array}{l}\text { Centre-periphery } \\
\text { Urban services; } \\
\text { Internal services; } \\
\text { Social networks. }\end{array}$ & $\begin{array}{l}\text { Private-public; } \\
\text { high-low } \\
\text { domination- } \\
\text { appropriation; } \\
\text { mobile-fixed; in-out; } \\
\text { central-peripheral; } \\
\text { near-distant; } \\
\text { demarcated- } \\
\text { oriented; change- } \\
\text { use; etc. }\end{array}$ & $\begin{array}{l}\text { Infrastructure } \\
\text { in general } \\
\text { (school, } \\
\text { market, } \\
\text { hospital, bank, } \\
\text { station, etc.) } \\
\text { makes a } \\
\text { syntagmatic } \\
\text { connection of } \\
\text { activities in } \\
\text { social space. } \\
\text { By means of } \\
\text { streets, } \\
\text { avenues, } \\
\text { roads, etc. }\end{array}$ & $\begin{array}{l}\text { Politics } \\
\text { happiness; } \\
\text { work; } \\
\text { cultural } \\
\text { heritage; } \\
\text { patriarchy; } \\
\text { gender- } \\
\text { based } \\
\text { violence; } \\
\text { etc. }\end{array}$ & $\begin{array}{l}\text { Work and } \\
\text { product for } \\
\text { the } \\
\text { realization } \\
\text { of the social } \\
\text { being } \\
\text { (everyday } \\
\text { life) }\end{array}$ & $\begin{array}{l}\text { Itineraries; } \\
\text { passing places; } \\
\text { shopping } \\
\text { centres; local } \\
\text { institutions and } \\
\text { infrastructures; } \\
\text { streets; } \\
\text { avenues; } \\
\text { squares; parks; } \\
\text { social centres; }\end{array}$ \\
\hline
\end{tabular}




\begin{tabular}{|c|c|c|c|c|c|c|c|c|c|c|c|}
\hline \multirow[b]{2}{*}{$\begin{array}{l}\text { Social } \\
\text { space }\end{array}$} & \multicolumn{3}{|c|}{ URBAN PHENOMENON PROPERTIES } & \multicolumn{3}{|c|}{ SCIENCE OF THE USE OF SPACE } & \multicolumn{3}{|c|}{ SEMANTIC DIMENSIONS OF URBAN SPACE } & \multirow[b]{2}{*}{ USE } & \multirow[b]{2}{*}{ CONTENT } \\
\hline & $\begin{array}{l}\text { Projection of } \\
\text { social relations }\end{array}$ & $\begin{array}{l}\text { Confrontation } \\
\text { of strategies }\end{array}$ & $\begin{array}{l}\text { Urban } \\
\text { practices }\end{array}$ & Formal Analysis & Functional Analysis & Structural Analysis & Paradigmatic & Syntagmatic & Symbolic & & \\
\hline 总 & $\begin{array}{l}\text { More abstract } \\
\text { general relations } \\
\text { financial and } \\
\text { energetic market } \\
\text { of capitals; spatial } \\
\text { policies. }\end{array}$ & $\begin{array}{l}\text { Alignment of } \\
\text { levels and } \\
\text { dimensions. }\end{array}$ & $\begin{array}{l}\text { Migration; } \\
\text { corruption; } \\
\text { terrorism; } \\
\text { tourism; etc. }\end{array}$ & $\begin{array}{l}\text { Place of the political, } \\
\text { institutional, } \\
\text { economic, } \\
\text { technological, } \\
\text { religious and scientific } \\
\text { power. }\end{array}$ & $\begin{array}{l}\text { Distribution of } \\
\text { resources; public- } \\
\text { private participation; } \\
\text { general organization } \\
\text { of traffic and } \\
\text { territorial, air, sea } \\
\text { subsoil transport. }\end{array}$ & $\begin{array}{l}\text { The logical, strategic } \\
\text { and ideological. For } \\
\text { example: the } \\
\text { communication } \\
\text { network. }\end{array}$ & $\begin{array}{l}\text { High-low; open- } \\
\text { closed; symmetrical- } \\
\text { asymmetrical; } \\
\text { horizontality- } \\
\text { verticality; mobile- } \\
\text { fixed; demarcated- } \\
\text { oriented; totality- } \\
\text { shredding } \\
\text { homogeneity- } \\
\text { difference; use- } \\
\text { change; centre- } \\
\text { periphery; } \\
\text { production-self- } \\
\text { destruction- }\end{array}$ & $\begin{array}{l}\text { Airports; ports; } \\
\text { stations } \\
\text { national and } \\
\text { international } \\
\text { terminals. }\end{array}$ & $\begin{array}{l}\text { Nature; } \\
\text { civilization; } \\
\text { world war; } \\
\text { religion; } \\
\text { culture; etc. }\end{array}$ & $\begin{array}{l}\text { Indirect } \\
\text { instrumental } \\
\text { use of } \\
\text { domination } \\
\text { and } \\
\text { exchange to } \\
\text { the global } \\
\text { homogenization. }\end{array}$ & $\begin{array}{l}\text { The public; } \\
\text { Political, } \\
\text { administrative } \\
\text { and superior } \\
\text { infrastructure } \\
\text { buildings; } \\
\text { monuments to } \\
\text { various scales; } \\
\text { public highway } \\
\text { infrastructure } \\
\text { and transport; } \\
\text { natural parks; } \\
\text { etc. }\end{array}$ \\
\hline
\end{tabular}




\section{References}

Betevé. (2017). Veïns de la Rambla, una espècie en extinció (TV segment). Betevé Redacció. Retrieved from http:// beteve.cat/veins-de-la-rambla-especie-en-extincio

CVD. (2017c). Memòria del procés participatiu de Pla d'usos de Ciutat Vella. Barcelona: BBC.

Lefebvre, H. (1972a). La revolución urbana. Madrid: Alianza. (Original work published 1970)

Lefebvre, H. (2014). Critique of everyday life. London: Verso. 